\title{
Aspectos de la monarquía Romana deL SigLO VI A.C. REFLEXIONES SOBRE LA TRADICIÓN
}

\author{
Aspects of the Roman Monarchy of the Sixth Century B.C. \\ Remarks about the Tradition
}

J. MuÑIz Coello

Universidad de Huelva

Recibido: 12/09/2017

Revisado: 28/05/2018
Aceptado: $31 / 05 / 2018$

Publicado: 29/06/2018

\section{RESUMEN}

La información proporcionada por la tradición literaria sobre la monarquía romana es escasa y de dudosa fiabilidad. Integrando en esta información, la aportación que supone el discurso del emperador Claudio al senado sobre el derecho de los galos a los honores, y las pinturas murales de la Tumba François de Vulci, realizamos un análisis crítico que nos lleve a una interpretación plausible de los datos, con relación a algunos aspectos de la monarquía romana del siglo VI a.C.

Palabras Clave Tulio.

Mastarna; Claudio; Vulci; Tarquinios; Servio

\section{ABSTRACT}

Report given by the literary tradition about the roman kings is scarce and vey uncertain. We must add the contribution of the Claudius emperor speech before the senate about the right of the gauls to the honores, and the wall pictures of the Tomb François of Vulci. Finally, we make a reflection in order to find a reasonable interpretation of the some aspects of the literary evidence about the roman monarchy of the sixth century B. C.

\section{KEY WORDS}

Mastarna; Claudio; Vulci; Tarquinios; Servio Tulio

coello@uhu.es 


\section{LA TRADICIÓN SOBRE LA MONARQUíA}

La historia de los tiempos más antiguos de la Ciudad fue asunto obscuro y difícil de abordar para los escritores clásicos, entre otras causas porque la historia como actividad tuvo unos comienzos muy tardíos y quienes se ocuparon del pasado no dispusieron apenas de documentos referidos a aquellos tiempos. La tradición literaria nos ha legado los nombres de poco más de una docena de autores romanos, conocidos como analistas por el modo de narrar los sucesos, que desde fines del siglo III a.C., escribieron sobre la Ciudad desde sus inicio. Pero sus relatos se perdieron y sabemos de ellos por citas puntuales indirectas, cortas referencias, muy contados fragmentos y meras alusiones en las obras de los historiadores posteriores que afirman que los utilizaron como fuentes. Fueron la base documental de nuestros dos principales historiadores augústeos - dejamos a un lado a Diodoro de Sicilia -, Dionisio de Halicarnasos, del que nos llegaron la mitad de los 20 libros de sus Antigüedades romanas, y Tito Livio, de quien apenas nos queda un tercio de los 142 libros de su historia desde la fundación de la Ciudad'.

Pero para el historiador actual la realidad es más sombría si descendemos al detalle. Dionisio de Halicarnasos dedica a la monarquía el 15\% del total de sus 20 libros, y de este porcentaje, a los reyes del siglo VI, poco más del 7\%. Visto desde otro ángulo, los 244 años que tradicionalmente se asignan a la monarquía romana se resuelven en tres libros y dos capítulos, mientras que para los 243 años que mediaban hasta el año 264, límite de la obra del griego, dedica los casi diecisiete libros restantes. Con Livio la información es aún más pobre. De los 142 libros de su ab urbe condita a la monarquía sólo dedicaba 55 capítulos de los 60 del libro I. Un $0.63 \%$ del total de la obra para cubrir casi dos siglos y medio. Y de esos 55 capítulos el siglo VI era cubierto en 25 capítulos, el $0.31 \%$ de la obra completa ${ }^{2}$.

1 Liv. praef. 6-7; 8.40.3-5. Los analistas, en general - Q. Fabio Pictor, L. Cincio Alimento, C. Acilio, A. Postumio Albino, L. Casio Hemina, L. Calpurnio Pisón, C. Sempronio Tuditano, C. Fannio, Sempronio Asellio, L. Celio Antípatro, Cn. Gellio, Q. Claudio Quadrigario, Valerio de Antium, L. Cornelio Sisenna, C. Licinio Macro y L. Elio Tuberón - . veían la monarquía como un proceso cíclico que comenzaba en lo bueno (Rómulo) y acaba en los malo (el Soberbio), Ogilvie, R.M., Roma Antigua y los etruscos. Madrid 1982, 22.

2 "Sesenta y tres años - pues tal es el lapso transcurrido desde el comienzo de la primera guerra púnica a la segunda - me han llevado tantos volúmenes como los cuatrocientos
Con todo, a veces no es éste el principal problema en el estudio del periodo. Frecuentemente lo difícil es sustraerse a la fascinación que sobre el historiador actual ejerce el relato clásico tradicional. Se trata de no quedar atrapado en la retórica del clásico, no sucumbir a sus propuestas y evitar asumir sin más las noticias y justificaciones que el escritor griego o latino utilizó, por más que no podamos construir y ofrecer un relato alternativo suficientemente convincente ${ }^{3}$. La mayor parte de lo que sabemos sobre la Roma Primitiva se escribió a comienzos del Principado, a más de cinco siglos de distancia, y los escritos que conocemos estuvieron impregnados de ideología, prejuicios, ficciones e intereses individuales y de clase, entre otras adulteraciones. Parece seguro que cada generación reelaboraba esa tradición ajustándola a la imagen que tenía de sí misma, de manera que a fines de la República lo que se conservaba, era un núcleo original de noticias modeladas con la suma de las inquietudes e intereses de cada época, a la que los historiadores del momento sumaron los propios ${ }^{4}$.

ochenta y ocho que van desde la fundación de Roma hasta el consulado de Apio Claudio, que comenzó la primera contra los cartagineses", Liv. 31.1.3. De las Antigüedades Romanas de Dionisio de Halicarnasos conservamos los diez primeros libros, el once casi entero y fragmentos del resto. Estos 11 libros contenían un total de 855 capítulos, una media de 77,7 capítulos por libro. Extrapolando esta media al total de los 20 libros de la obra, tendríamos un total de 1.554 capítulos. Los porcentajes se extraen a partir de esa fórmula. En autores como Diodoro de Sicilia, Veleyo Patérculo o Dión Casio el tema es tratado de forma aún más abreviada, mediante breves alusiones y referencias, y todo en fragmentos. El panorama ciertamente no es estimulante. Algunos autores omitieron a Tulio en la relación, aunque puede tratarse de algo involuntario, Verg. aen. VI. 810/817; Str. 5.2.2.

3 Si tuviésemos más documentos arqueológicos, la historia de la Roma primitiva sería muy diferente a la transmitida por la tradición, POUCET, J., Les rois de Rome. Tradition et histoire. Bruxelles, 2000, 10; Momigliano, A., Ensayos de historiografía antigua y moderna, [Wesleyan University Press 1947]. México 1993, 94; idem, «An Interim Report on the Origins of Rome», JRS 53, 1963, pp. 95/121, 95.

4 Ficción e historia, este es el material literario para el estudio de la Roma Primitiva, Poucet, J., Les rois, op. cit. p. 11. Partiendo de esta idea de Cornell, T.J., «The value of the Literary Tradition concerning Archaic Rome», Social Struggles in Archaic Rome. New Perspectives on the Conflict of the Orders, ed. by K. A. Raaflaub, [The University of California Press, 1986], Oxford 2005, pp. 47-74, 50, ampliamos su contenido: la tradición recoge las preocupaciones del hombre de finales de la República, y en menor medida, las de las generaciones anteriores. En esta 
El presente trabajo se va a centrar en los reyes del siglo VI, que son considerados más auténticos por la crítica. Analizaremos los datos biográficos de L. Tarquinio Prisco, con relación a los de su antecesor y sus sucesores. La personalidad de Servio Tulio, un monarca de nombre latino inserto entre dos etruscos, desde la tradición literaria y las perspectivas que podemos inferir a partir de dos documentos fundamentales, que no pueden estar ausentes de cualquier enfoque, como son el discurso del emperador Claudio al senado del año 48, y las pinturas murales de la Tumba François de Vulci. Finalmente, aludiremos a L. Tarquinio el Soberbio y la tradición acerca del fin del régimen.

Como hemos indicado, básicamente toda la documentación sobre estos monarcas está en la tradición literaria. En general, la República tuvo un recuerdo negativo de sus reyes, a los que los historiadores de tiempos de Augusto calificaban de pastores aborígenes, arúspices sabinos (Numa), y siervos o hijos de esclavos etruscos (Tulio), considerando algún autor paradójicamente al último, el Soberbio, como el más honroso ${ }^{5}$. La información que Livio disponía sobre la monarquía y los tiempos inmediatos era ciertamente escasa y de poca fiabilidad, según él mismo confesaba. La realidad era que esa inconsistencia se prolongaba hasta el siglo IV, pese a la declaración optimista del autor por los nuevos tiempos que Roma iba a disfrutar tras la salida de los galos de la Ciudad en el 390 a.C. Este suceso, por lo demás, según el propio historiador, acabó con la mayor parte de los documentos, públicos y privados, todo lo cual explicaba que para cubrir los casi cinco siglos que iban desde la fundación hasta el comienzo de la Primera Guerra Púnica, consulado de Ap. Claudio (Caudex), año 264, dedicara sólo quince libros, el mismo número que para los sesenta y tres años que iban del comienzo de aquella primera guerra hasta el año final de la segunda ${ }^{6}$.

línea, GABBA, E., «Problemi di método per la storia di Roma Arcaica», Roma Arcaica. Storia e Storiografía, Roma 2000 , p. 12.

5 Just. 38.6.7; Gell. 5.18.8/9. Sólo es válida la historia en cuanto modelo moral; Cic. rep. 2.37; 49; imperium regibus abrogatum, Floro, epit. 1.212; App. BC. 2.107/109. GiUA, M.A., "La valutazione della monarchia a Roma in etá repubblicana», SCO 16, 1967, pp. 308-329; D. Briquel, Pastores aboriginum (Justin, 38, 6, 7): à la recherche d'une historiographie grecque anti-romaine disparue, $R E L 73,1995,44-$ 59.

6 Liv. 6.1.2; 8.40.3-5; Plut. Numa, 1. 1-2. Vid. MARTINEZ-PinnA, J., "Aspectos de cronología romana arcaica. A
La lista real completa, extendida a lo largo de 244 años, ha suscitado siempre un lógico escepticismo. Y como ocurre cuando la información sobre un tema es escasa y de calidad sospechosa, se abre el campo de las especulaciones, de las conjeturas y las hipótesis peor o mejor construidas. Cuando las fuentes arqueológicas no se incrementan de forma cualitativa, y sus resultados ya han sido incorporados al discurso historiográfico, sólo nos queda seguir trabajando con las fuentes literarias, la tradición, y esperar interpretaciones imaginativas que abran perspectivas más ajustadas para una mejor comprensión y reconstrucción de los hechos. De momento, las opiniones abarcan todo el espectro de posibilidades con relación a la monarquía. Por citar un ejemplo, para J. Gagé la falta de fiabilidad abarcaba hasta el comienzo de la República: los personajes de ambos periodos eran tan irreales para el sabio francés, como los de la tragedia griega. Para otros, sólo eran fiables los tres últimos reyes, los que cubrían el siglo VI, pues con los datos de la analística se consideraba imposible reconstruir nada sobre los cuatro primeros ${ }^{7}$.

Los reinados de estos tres monarcas son ciertamente largos, de treinta y ocho, cuarenta y cuatro y algo menos, pero aún dilatado, el tercero, de veinticinco años, respectivamente. Tal extensión no era infrecuente en las antiguas monarquías mediterráneas. A nuestro entender, las dudas surgen no tanto por la duración de los reinados, similar a la de los otros cuatro monarcas, cuya media es de casi 35 años, como porque a lo largo de un siglo - o dos y medio, si lo extendemos a toda la monarquía -, ningún suceso fortuito, ningún acto violento y azaroso, que los hubo, cualquier imprevisto, truncó o interrumpió precozmente un reinado, al poco tiempo de su comienzo, por ejemplo. Situación que era frecuente en esos tiempos, sobre todo si lo cotejamos, por ejemplo, con la suerte de los emperadores del siglo I d.C. Aunque dos de los tres reyes del

propósito de la lista real", Latomus 48.4, 1989, pp. 798-816.

7 La bibliografía es enorme. Significativas fueron las posiciones de GJerstad, E., Early Rome, V, Lund 1973, p. 214; Poucet, J., Les rois, op. cit. p. 181; Momigliano, A., "The origins of Rome», CAH VII.2, [1983] 2006. pp. 52-96, 87; OgIlvie, R.M., op.cit. p. 31; CoRnell,T.J., Los orígenes de Roma, c. 1000 - 264 a.C. Barcelona 1999; idem, "The value», op.cit. p. 48. Aunque en la duración de los reinados se sigue a Livio y Dinisio de Halicarnasos, hay discrepancias, por ejemplo en Polibio, cuando asigna 39 años de gobierno a Numa, y 23 a Anco Marcio, Cic. rep. 2.14.27; 18.33. 
siglo VI fueron asesinados, ello ocurrió cuando los monarcas ya eran viejos y después de haber ocupado el trono durante décadas, y resulta especialmente llamativo que el último, el odiado Tarquinio el Soberbio, muriera a la avanzada edad de noventa años, bajo la protección del tirano de Cumas, suponemos que de muerte natural, si hemos de creer a nuestras fuentes escritas ${ }^{8}$.

Los largos reinados y el escaso número de reyes obligaron a la tradición a complejas explicaciones y artificios a la hora de conformar y dar verosimilitud a los entramados genealógicos de las familias, y poder así acreditar las sucesiones. Pero aún de esta forma el resultado resiste mal el análisis detenido de un historiador como Dionisio de Halicarnasos, que dedicaba espacio a exponer las incongruencias de algunos de estos aspectos. Para crear un cuadro plausible y equilibrado de conexiones familiares que dieran legitimidad a las sucesiones, la tradición aumentó las edades y postergó los nacimientos hasta márgenes improbables, adecuando y conformando así un cuadro cronológico con tan escaso número de personajes?.

8 GAGÉ, J., L a chute de los Tarquins et les debuts de la Republique Romaine. Paris 1976, p. 7. La lista de los quince reyes albanos, sin contar a dos, que se mantuvieron 13 y ocho años, reinaron una media de 31,6 años, Dion. Hal. ant. 1. 71. En Pérgamo, Atalo I Soter (241/197), Eumenes II (197/160) y Atalo II (160/138), tienen reinados de 44, 37 y 22 años respectivamente. Pero los dos siguientes, Atalo III (138/133), y Eumenes III (133/128) sólo gobiernan cinco años cada uno. En Bitinia de los diez reyes constatados entre el 328 y el 90 a.C., un periodo casi similar al romano, con 238 años, siete sobrepasan los veinte años, de los que dos, el fundador Cipetes (328/279) y Prusias I (228/185), reinaron más de cuarenta, y otros dos, más de treinta. Pero Etazeta (255/254), lo hizo sólo un año y Sócrates (90/85), cinco. De los diez reyes de Capadocia documentados, Ariaramnes II $(280 / 230)$ y Ariarates IV Eusebio (220/163) sobrepasan los cincuenta años de reinado, y otros dos, los treinta, Ariarates III $(255 / 220)$ y Ariarates V Eusebio Filopator (163/130), pero hay otros dos, Amiertes (317/315) y Ariarates VIII (101/96) con dos y cinco años respectivamente. Finalmente, entre los Seleúcidas, junto a Seleuco II Calinicos $(265 / 226)$, con 39 años, y Antíoco III el Grande (223/187) con 36, tenemos a Antíoco II Theos $(261 / 246)$ con 15 y Seleuco III Soter $(226 / 223)$, con tres.

9 Dion. Hal. ant. 4.6; 30.2-3; Liv. 1.46.4. Sobre el parentesco de los Tarquinios, Dion. Hal. ant. 3.72.1; 4.6.3/4; 4 . $6.5 ; 7.3 / 5 ; 64.1 ; 6.11 .2 ; 21.3$. Prisco, padre de Soberbio, Pisón, fr.15 P; L Junio Bruto, nieto del Soberbio, a través de Tarquinia, una hermana de éste, casada con M. Junio Bruto, Dion. Hal. ant. 4.68.1; 72/75; 77/81; CAIro, G., «A propósito delle tradizioni sui Tarquini», Gerion 28.1, 2010, pp. 75/95.
Poca reserva hay sobre el gobierno del primer Tarquinio. Hijo de Demárato, un rico comerciante corintio del clan de los Bacchiadas que se vio afectado por la llegada al poder en el 657 del tirano Cipselo, pasó a Etruria, asentándose en Tarquinia, ciudad que conocía por sus contactos comerciales previos. La tradición indica que allí se casó con una ilustre nativa y se fue integrando paulatinamente en los grupos más influyentes de la ciudad. Más allá del relato verosímil o no que la tradición nos transmite, fue un hecho que en el siglo VII hubo importante comercio de corintios en Etruria y que de la misma forma, hubo artesanos y trabajadores en Etruria de aquella ciudad griega ${ }^{10}$. Demárato tuvo dos hijos Arrunte y Lucumón, el futuro rey Tarquinio Prisco. Con el tiempo éste último se establecería en Roma, contactando con la corte del rey Anco Marcio, con el que colaboró en empresas militares durante parte de su reinado. Ya en el trono se le adjudican dos campañas militares contra los sabinos, la segunda de cinco años de duración, a los que capturó Colatia, que entregó a su sobrino Egerio, el hijo de su hermano fallecido de igual nombre, que desde entonces tomó el apodo de Colatino. El rey luchó contra los etruscos durante nueve años, donde sobresalió por fuerza y valor uno de sus generales, Servio Tulio, extranjero y apátrida; contra los volscos, a los que tomó Apiolae, identificada con Suessa Pometia, y finalmente, contra los latinos, a los que tomó las villas de Nomento, Cornículo, Ameriola y Medulia, entregándosele sin lucha Ficulae, Crustumerio

Marcio acogió a Lucumón, porque éste, que era muy rico, le dijo que le iba a dar toda su hacienda. La tradición explica el modelo de integración de un extranjero, como Prisco, en una sociedad ajena, como la romana, manejando los elementos que a fines del República, daban verosimilitud a este fenómeno. Riqueza, generosidad y acogimiento eran claves para eliminar tensiones y recelos entre desconocidos, y abría al etrusco Prisco el camino a los círculos de los poderosos, Liv. 1.34.11/12; Dion.Hal. ant. 3.48.1.

10 Dion. Hal. ant. 1.75.2; 3.46.3-5; 72.1; Liv. 1. 34.2-3; Zon. 7.8.1; sobre Anco Marcio, Martínez-PinnA, J. «La Roma de Anco Marcio», Gerion, 6, 1988, pp. 56-88; GANTZ, T.N., "The Tarquin Dynasty», Historia: 24.4, 1975, p. 541; Hammond, N.G.L., "The Peloponnese», CAH III.3, [1982] 2006, pp. 335 y 344; Martinez-Pinna, J., Tarquinio Prisco. Madrid 1996, p. 86, considera que Tarquinio Prisco no procedía de Tarquinia sino de Caere. Para Blakeway, A., «Demaratus: A Study in Some Aspects of the Earliest Hellenisation of Latium and Etruria», JRS 25, 1935, pp. 129149,148 , la historia de Demárato y Lucio Tarquinio era una ficción embellecida. 
y Camerium. En su actividad civil se destaca la construcción de tiendas y pórticos en el foro, una muralla para la Ciudad, las cloacas de Roma y el Circo Máximo ${ }^{11}$.

Las dudas surgen con la noticia que le señala como el constructor del Templo de Júpiter en el Capitolio. La tradición informa que la edificación se extendió a lo largo de todo el siglo VI, algo difícil de justificar con independencia de que no tengamos otra certeza de los hechos. Según ésta, Tarquinio Prisco allanó el terreno para dar cabida a un edificio de magnitudes importantes. Amuralló el espacio de alrededor y rellenó con arena el hueco que se produjo entre el muro y la colina; finalmente, encargó al artista Vulca de Veyes la estatua de Júpiter y la cuadriga, que iba a presidir el tímpano del templo. Esta estatua, si existió, iba en arcilla pintada luego con cinabrio.

La misma tradición atribuye al segundo Tarquinio la colocación de los cimientos y buena parte, sin precisar, del resto del edificio; fue él, y no Prisco, quien encargó a escultores etruscos las estatuas necesarias, que fueron entregadas en los primeros años de la República. Para una parte de la crítica actual, la planta de aquel templo era un períptero sine postico, que no parece haber existido en el Mediterráneo antes del siglo IV, lo que no obsta para que en la colina del Capitolio hubiese en efecto, existido un templo a fines del siglo VI pero de tamaño muy inferior al famoso. Lo relevante de la noticia en general es que la erección de aquel monumento religioso dejaba prácticamente fuera del proceso constructivo al rey Tulio, al que sólo una referencia indirecta, por lo demás poco convincente, le hacía partícipe de las obras, lo que de admitirlo sin críticas, nos llevaría a la conclusión no menos extravagante, de que las obras del templo se iniciaron con Prisco, estuvieron detenidas durante 44 años con Tulio, un rey cuya labor se calificó como básica para la futura grandeza del Imperio y auténtico defensor de la libertad y la justicia de los ciudadanos, un verdadero nacionalista entre dos etruscos, pero fueron terminadas por el Soberbio y finalmente dedicadas por los primeros cónsules de la República ${ }^{12}$.

11 Liv. 1.35; 37-38; Dion. Hal. ant. 3.49.1-5; 50.1/4; 51.2; 55-59; 62.2; 64; 65.3; 65. 6; 67.4/5; 68.2; Str. 5.3.4; Plin. nat. 3.70; PAIs, E., Storia critica, op. cit. p. 347, n. 2; MARTINEZ-Pinna, J., «Tarquinio», op. cit. p. 239.

12 Plin. nat. 35. 157; Plut. Public. 13; Dion.Hal. ant. 3.69.1-2; 4.2.2;16.1; Liv. 1.39.3; 42.5. Para Holloway, R., The Archaeology of Early Rome and Latium. Londres-New
Pensamos que en la elaboración de este episodio se intentaron conciliar dos elementos importantes: uno, la necesidad de nacionalizar la consagración del templo más emblemático del estado republicano, sustrayendo su dedicación final a los reyes etruscos - a partir de la imagen que a fines de la República, cuando esta tradición se reelabora, se tenía de los etruscos -, y asignándolo a los magistrados republicanos, para no herir los sentimientos patrióticos posteriores, y dos, la distribución de los hechos de manera que no hubiese desconexión temporal, un intervalo entre el rey que lo construye y los cónsules que lo dedicaron e inauguraron. La tradición prefirió distribuir las diversas etapas de las obras entre los dos Tarquinios, aún a costa de crear un hiato extravagante sin actividad constructiva con Tulio, en vez de limitar su realización a uno sólo de los Tarquinios, según más adelante consideraremos, aquel que diera paso a los nuevos magistrados de la República ${ }^{13}$.

Debemos hacer aquí una digresión que consideramos útil para entender ciertos hechos. Nos referimos al fenómeno de la duplicación de episodios, algo frecuente en el relato clásico. Expulsado ya el último Tarquinio, la llegada de un nuevo adversario etrusco al pie de Roma da lugar a episodios que evocan a alguno de los ya protagonizados por aquel rey. Se trata de la guerra de Porsena y la ciudad de Aricia, análoga a una actuación similar del Soberbio y esa ciudad latina. Con el Soberbio esta guerra

York, 1994, p.10, el escultor Vulca de Veyes, que esculpió las estatuas de bulto y terracotas del Templo de Júpiter, no existió. Cic. Verr. 2.5.19.48 apunta la anécdota de que el templo fue construido por trabajadores que tuvieron que hacerlo sin cobrar salario, obligados; Martinez Pinna, J., «El primitivo Templo de la tríada capitolina en Roma», Bol. Real Acad. Bellas Artes de San Fernando, 48, 1979, pp. 217-239; idem, «Evidenza di un tempio di Giove Capitolino a Roma all'inizio del VI sec. a.C.,» Archeologia Laziale, 4, Roma, 1981, pp. 249-252.

13 Poucet, J., Les rois, op.cit. 234; Gantz, T.N., «"The Tarquin", op. cit. pp. 539-554; la afirmación de mox Servius Tullius sociorum studio, Tac. hist. 3.72 de que Tulio continuó las obras del Templo de Júpiter, puede tratarse de una certeza sobreentendida, originada por la ubicación del monarca entre quienes se atribuyen su participación en la obra, Cornell, T.J., Los orígenes, op. cit. pp. 157 y 160. Hay quien, como J. Martinez-Pinna, "Tarquinio», op. cit. p. 238, simplemente no da importancia a la presencia de duplicidades, repeticiones, contradicciones y anacronismos en los textos de los historiadores y lo califican de mero peaje por las precarias condiciones de la redacción del relato analístico. 
se solventó como un litigio casi privado, a causa del despecho del líder de los aricinos, Turno Herdonio, por no haber sido elegido yerno por Tarquinio, que prefirió para su hija al princeps de Túsculo, Mamilio Octavio. La pugna se solventó con la muerte de Herdonio. Poco después, Arrunte, hijo de Porsena, pone sitio a Aricia y tras dos años de iniciativas infructuosas por parte etrusca, aricinos y aliados cumanos de Aristodemos derrotan a Arrunte, que muere en el combate, y Porsena decide la retirada. Ambos sucesos, la guerra contra Aricia de Tarquinio y luego la de Arrunte, hijo de Porsena, aparecen deslavazados e incoherentes en sus contextos, alimentando la hipótesis del desdoble o duplicación de un único suceso en dos episodios, el protagonizado por Tarquinio y el de Arrunte, hijo de Porsena. Tampoco puede soslayarse la figura del rebelde y agitador Turno Herdonio de Aricia. Cincuenta años más tarde - hacia el 460 a.C., - otro Herdonio, Apio, igualmente tan rebelde y agitador como rico y notable entre los suyos, lideraba una rebelión contra la República, ahora al grito de libertad para los esclavos y regreso de los exiliados, llegando a ocupar el Capitolio. Como ocurrió con el primer Turno, la intentona del segundo fue finalmente sofocada y su líder ejecutado. Es igualmente coincidencia, que en la derrota de este segundo Herdonio, participó un tal L. Mamilio, dictator de Túsculo ${ }^{14}$.

Los sucesos con semejanzas significativas rebasaron a veces el relato romano y mostraron analogías con la historia griega, como los 306 Fabios del rio Cremera, o los 300 espartanos de las Termópilas. Indicaban los textos que el rey Tulo Hostilio fue asesinado por un nieto de Numa, que veía que no iba a ser rey, la misma causa que afectó a Tarquinio Prisco, asesinado por los hijos de Anco Marcio, y la de Servio Tulio, por el hijo, o más bien e nieto de Prisco, Tarquinio el Soberbio ${ }^{15}$. Con los Tarquinios

14 Liv. 1. 49.9; 50.3; 9; 51; 2.15/18; Dion. Hal. ant. 4.45.4: 46.4; 48.2; 5. 36; 10.14.1-2; 16.7. Para Dionisio de Halicarnasos Apio Herdonio era de Corila, acaso Coriolos, cerca de Aricia, vid. Martínez Pinna, J., El intento revolucionario de Apio Herdonio, Gerion 5, 1987, pp. 87-96. Sobre Porsena, Gjerstad, E., «Porsenna and Rome», Orom 7, 1969, pp. 149161; Scevola, M.L., "Conseguenze della deditio di Roma a Porsenna», RIL 109, 1975, pp. 3-27; Hafner, G., «Porsenna», $R d A$ 1, 1977, pp. 36-43; Heurgon, J., «La coupe d'Auulus Vibenna", Scripta Varia, Bruxelles, 1986, pp. 273/283.

15 Dion. Hal. ant. 2. 58.2; 76.5; 3.35.4; 72.1; 4.38.4; Liv. 2.48/50; Ovid. fast. 2.195/242; Gell. 17. 21.4. Tanto Tito Tacio, como Aulo Vibenna, y Porsena, que podría ser L Junio Bruto, al comienzo de la República ejercieron en Roma un se distribuyen sucesos de similitud sospechosa, que podrían ser consecuencia del manejo interesado de la tradición por el deseo de los autores de ofrecer un relato acabado de los hechos. Así, se nos repite para ambos monarcas el desecamiento de terrenos situados en los barrios bajos, el episodio de los nueve libros sibilinos, la toma del poder con violencia, la existencia de un hermano del mismo nombre, Arrunte, o la citada construcción del templo de Júpiter Capitolino, usando el botín tomado en Apiolae o en Suessa Pometia, que es otra forma de nombrar la misma ciudad, y otros sucesos ${ }^{16}$.

Los historiadores que escribieron con Augusto, en líneas generales estuvieron de acuerdo con la tradición existente sobre los reyes del siglo VI a. C. Se asumía como hecho indiscutible que Roma tenía una deuda con el legado etrusco, que podía percibirse en los monumentos y restos de edificaciones, en muchos símbolos e instituciones, en formas del rito y protocolos cultuales, en fin, en la memoria de las numerosas guerras que la Ciudad había mantenido con los etruscos desde los tiempos más antiguos. Personajes como el último Tarquinio, Por-

poder de tipo real, Grandazzi, A., La fondation, op. cit. p. 268. En aplicación de la teoría de las constituciones, un sistema político, como era el decenvirato, sólo podía ser sustituido cuando entraba en descomposición. Como era contradictorio que un gobierno bien considerado mutara radicalmente en abusos e iniquidad, sin que cambiaran los personajes, el escritor podía resolver el dilema creando una segunda comisión, a la que además se le asignaron las leyes más problemáticas, cuyos actos justificaran el fin de ese ciclo. De la misma forma que el final de la monarquía sólo podía justificarse con un último rey malo, desde luego no romano, que concentrara los actos de gobierno suficientemente nefastos como para justificar el fin del viejo régimen y la llegada del nuevo.

16 Prisco solo hizo la plataforma, la obra se interrumpe con Tulio, y fue retomada por el Soberbio, Liv. 1.38.6; 53.3; 55.8; 56.3; Plin. nat. 3.70; Dion. Hal. ant. 3.67.5; 4.44.2; Pais, E., Storia critica, op. cit. p. 346; Heurgon, J., Roma, op. cit. pp. 150, 159 y 228; Cornell, T.J., Los orígenes, op. cit. p. 159; el sobrenombre de Prisco, no es posible sin un Tarquinio posterior, L. Bianchi, «Il magister Servio Tullio», Aevum, 59.1, 1985, pp. 57-68, 64; los dos Tarquinios son la misma persona, Sanctis, G. de, "Mastarna», Klio II, 1902, p. 102; el Soberbio, el único existente, F. Castagnoli, F., «Topografía e tradizione storiografica su Roma Arcaica», $A R C L$ 25/26, 1973/1974, p. 127; por el contrario, Fraccaro, P., «The History of Rome in the Regal Period» JRS 47, 1957, p. 64, siempre pensó en dos reyes; Martinez- Pinna, J., Tarquinio, op. cit. pp. 65-69. El episodio de los libros sibilinos, con el Soberbio, Zon. 2.11.1; Dion.Hal. ant. 4.62. 
senna, Arrunte o ya más tarde, Tolumnio de Veyes ${ }^{17}$ evocaban un pasado de episodios hostiles, pero era un hecho que en los comienzos de la analística, la sumisión de Etruria a Roma ya contaba con dos siglos de antigüedad, y era deuda de la tradición articular esta doble y contradictoria realidad, la de los tiempos de una Etruria dominadora y los tiempos de una Etruria dominada, y presentar con todo ello un argumento que pudiera ser asumido como posible. Así, se llegó a una versión que confirmaba la presencia de reyes etruscos en Roma, pero sin referencia a que fuera el resultado de una guerra o invasión que abriera un período de dominación etrusca. De esta forma, los reyes etruscos llegaron al trono de Roma como consecuencia de complejas maniobras políticas en sus relaciones familiares, o de conspiraciones que luego fueron legitimadas, todo ello acaecido en los aledaños del poder, sin que mediara invasión y captura de la Ciudad ${ }^{18}$.

Presentandos los sucesos como secuela de relaciones dinásticas y personales, el historiador escamoteaba cualquier explicación sobre el protagonismo del cuerpo social, esto es, de la reacción de las instituciones, o de los diversos sectores de la población respecto al poder, o el interés y beneficio de las grandes familias en los sucesos. Todo quedaba en el ámbito de los actos individuales, y era desde este ámbito y sus aledaños, donde se aportaban las convenientes justificaciones y respuestas a los hechos. No olvidemos que este modelo narrativo encajaba bien con la versión idealizada con que los autores republicanos enfocaron el pasado, y que ya R. Syme dejara bien identificada ${ }^{19}$.

17 Lars Tolumnius, rey de Veyes, muerto en combate singular en guerra contra los romanos en 436/5 a.C. Ampelius, mem. 2.1.2; Cic. phil. 9.4.2; Floro, epit. 1.6.23; Liv. 4.17.2; 18.2; 58.7; Val. Max. 9.9.3. A comienzos del Principado las fases previas a la última centuria republicana se idealizaron, se asumieron como mejores y se evocaban desde la nostalgia, como recuerdo de los tiempos austeros en una República sin riquezas, Tac. ann. 2.33.2; 3.54.3, la recuperación de monumentos y ritos antiguos, de Augusto, Suet. Aug. 29-31; GrandaZzI, A., La fondation, op. cit. p. 48.

18 Tac. hist. 3.72.5, asume la Ciudad como tomada por el etrusco Porsenna. La llamada movilidad horizontal en la Italia Primitiva, Roma incluida, fue un constatado, como indicó C. Ampolo, La nascitá della cittá, Storia di Roma, 1. Roma in Italia, Torino 1988, 175.

19 Verg. aen. 6.810-818; para Str. 5.2.2. "Los ornamentos triunfales, insignias de los cónsules, los emblemas de los magistrados, fasces, hachas, trompetas, ceremonias religiosas, arte adivinatoria, música, todo esto fue llevado a Roma desde Tarquinia. Las distorsiones patrióticas ocultaron la
En la cronología tradicional el rey Servio Tulio era el sucesor del primer Tarquinio. Se le hizo responsable de reformas que resultaron fundamentales para el futuro régimen republicano, y no podía ser el último rey de aquella monarquía, pues éste, el último, debía estar caracterizado como un personaje cruel, injusto y tiránico, que justificara plenamente el cambio de sistema y la devolución del poder a los nobles, según la teoría de la evolución cíclica de las constituciones. Por todo ello, su ubicación en la lista real se justificaba en penúltimo lugar, antes del rey tirano, y en consecuencia, entre los dos Tarquinios.

Para la tradición romana, Servio Tulio era hijo de un tal Espurio Tulio - o nullo patre, en otra fuente -, un princeps latino de la villa de Cornículo, y de una tal Ocrisia, una mujer hermosa y prudente, que fue hecha prisionera cuando Tarquinio Prisco tomó su ciudad, y que al poco ya en Roma daría luz al futuro rey Tulio. La biografía de éste no dejaba duda sobre los altos designios que le iba a deparar la providencia. Desde el presagio de la llama en su cabeza, su visible carácter regio, consecuencia de la nobleza singular de su madre, en una de las versiones de la tradición, las virtudes le acompañaron igualmente en la juventud, cuando con apenas veinte años, sirvió en el ejército de Prisco contra los tirrenos, en la ciudad de Ereto, y más tarde contra los sabinos, como general de los aliados latinos, unas veces al frente de la caballería y otras de la infantería ${ }^{20}$.

realidad de la dominación etrusca”, WALsh, P.G., Livy, his historical aims and method, Cambridge 1961, p. 19; SCULLARD, H.H., History of the Roman World, 753-146 B.C. London 1980, p. 53; a la analística ortodoxa transmite una intervención etrusca no violenta, POUCET, J., Les rois, op. cit. p. 210. "La política y la actuación del pueblo romano estaba regida por una oligarquía: sus anales fueron escritos con un espíritu oligárquico. La historia nació del archivo de las inscripciones del consulado y triunfo de los nobles, de las tradiciones relativas a los orígenes, alianzas y disputas de sus familias; y la historia nunca renegó de sus comienzos. Por necesidad, la concepción era estrecha; sólo la clase gobernante podía tener historia de algún género, y sólo la ciudad gobernante: sólo Roma, no Italia”, Syme, R., The Roman Revolution. Oxford 1939, p. 120.

20 Liv. 1.39.1; 4-5; 41; 4. 3.10-14; Dion. Hal. ant. 4.1.23 ; .2.1-4; 3.1/3; .6.6; DC 1.9; Zonaras, 7.8.13; Festo, 486L, Ogilvie, R.M., op.cit. p. 63; Martinez-Pinna, J., Los reyes de Roma entre la leyenda y la historia, Gerion 19, 2001, p. 697; idem, «Tarquinio» (cit. n.13), pp. 259 y 274. Para este autor, no hay necesidad de demostrar la falsedad e increíbles versiones que se dan de los comienzos de la biografía de 
No es de este estudio tratar en profundidad la interesante figura del rey Tulio, sino sólo en los aspectos que interesa al caso. El relato tradicional lo consagra como un rey eficaz y provechoso, cuyas medidas hicieron posible el desarrollo de la posterior República. Dionisio de Halicarnasos le llama basilueus, frente al tirannos Soberbio e incluso el monarchos, Rómulo. Fue un rey bondadoso, benefactor y magnánimo, el último rey legítimo y justo. Tácito recordaba a Servio Tulio como autor de normas que afectaban a todos, pues ni aún los reyes podían desobedecerlas. Su estatua se guardaba en el Templo de Fortuna, y su toga se conservó hasta la muerte de Sejano, año 31 d.C., lo que supone más de cinco siglos y medio. La imagen populista de un rey Tulio, que saldaba deudas, distribuía tierras entre los más necesitados y concedía ciudadanía a los libertos, como pago por el voto popular recibido para hacerse con el trono, parece elaborada por la analística del tiempo de los Gracos ${ }^{21}$. Si para Dionisio lo que distinguía una verdadera ciudad de una villa o aldea era la presencia de una muralla, si tal elemento constructivo simbolizaba el paso de un grado a otro de progreso como se comprobaba entre los sículos, cuyas aldeas dispersas por las montañas fueron sustituidas por las ciudades amuralladas de los pelasgos, con el rey Tulio la Ciudad dejó atrás su imagen de villa o aldea y como en una nueva refundación, Roma se convirtió en una verdadera ciudad, gracias a la muralla que este rey construyó ${ }^{22}$.

\section{Servio Tulio.}

21 Plin. nat. 8.197; Val. Max. 1.8.11; Tac. ann. 3.26; Gabba, E., «Studi su Dionigi da Alicarnasso, II», Athenaeum 39, 1961, p. 118; Dion. Hal. ant. 4.9.6-7; 9.9; 10.1-3; 11.2; 12.3; 13.1; 22.4; Liv. 1.48.8; Thomsen, R., King Servius Tullius: a historical synthesis. Copenhague 1980; Martinez-Pinna, J., "Tarquinio Prisco y Servio Tullio», AEA, 55, 1982, pp. 35-61; Richard, J.-Cl., "L'Oeuvre de Servius Tullius: Essai de mise en point», RHDFE, 61. 1983, pp. 181-193; idem, «Recherches sur l'interpretation populaire de la figure du roi Servius Tullius», Revue de philologie, de litteraire et d'histoire anciennes. 61,2. Paris, 1987, pp. 205-225; Bianchi, L., "Il magister», op. cit. pp. 57-68; Capdeville, G., «Le nom de Servius Tullius'm, in AA.VV., La Rome des premiers siècles. Légende et histoire. Actes Table Ronde en l'honneur de M. Pallottino (Paris 1990), Firenze 1992, pp. 47-67; Vernole, V.E., Servius Tullius. Roma 2002.

22 Roma era ciudad desde su fundación, pues tenía muralla desde el principio, Dion. Hal. ant. 1.9.2; 45.3; 2.2.1-3; 3.1; una primera muralla ya en el mismo momento fundacional, Dion. Hal. ant. 2.2.1-3; 3.1; con Tulio, las tres tribus iniciales se transforman en cuatro y el nuevo muro engloba
El latino Servio Tulio, que guerreaba contra los sabinos, como general de Prisco, era en alguna fuente considerado extranjero y apátrida, como supra dijimos. La tradición indica que Tulio lideraba las tropas de Prisco, pero es posible que en realidad fuera un mercenario que guiaba sus propias tropas, aunque al servicio ahora del etrusco. Tal relación es igualmente descrita antes para el mismo Tarquinio Prisco con relación a su antecesor Anco Marcio. Las familias de Prisco y Tulio eran consideradas pujantes en sus villas de origen, Tarquinia y Cornículo, por tanto con capacidad para liderar contingentes militares a sus expensas. En la tradición esta clase de personajes poderosos tuvo homólogos como el sabino citado Apio Herdonio, el volsco Coriolano, Clausus - el primero de los Claudios -, los 306 Fabios, Espurio Casio, Espurio Melio y Manlio Capitolino, individuos que afrontaban combates con sus propios seguidores, amigos y clientes ${ }^{23}$.

Pero el papel más importante que la tradición asignó al rey Tulio fue la de instituir el primer censo, y con ello, la reordenación de los ciudadanos y la política en función de sus niveles de riqueza, distinguiendo entre dignidad y riqueza y distribuyéndoles en classes y centurias. Un censo que repetió tres veces a lo largo de sus cuarenta y cuatro años de reinado, como el que veintitantos años antes realizara Solón en Atenas, un legislador muy presente en los círculos intelectuales de final de la República. Tal nueva estructura, que omitimos describir por ser tema muy tratado por la historiografía, entraría en pleno funcionamiento supuestamente veintinco años después de la muerte del monarca, ya en la República, como asamblea ciudadana, con funciones legislativas, electorales y judiciales, siendo la base de la constitución republicana. La tradición adjudicó esta reforma al rey Tulio, un latino insertus entre dos

siete colinas, Dion. Hal. ant. 4.13.3; 14.1; Liv. 1. 44.3.

23 Dion. Hal. ant. 3. 35. 3; 39.2; 40.4; 41.4; 46.1; 65.6; 4.3.2; 6.4; DC I.9. En la tradición, Prisco fue magister equitum de Anco Marcio, y Servio Tulio, de Prisco, Bianchi, L., "Il magister», op. cit. p. 61. La elección como monarca de Prisco se "republicaniza" haciendo intervenir a los interreyes. Es la asociación al poder que durante la República se conocía del magister equitum con el magister peditum o dictator. En otros tiempos y culturas se construyen igualmente fórmulas de conexión con el poder y así, Sargón de Akkad fue copero y jardinero de Urzababa de Kish, veintitrés siglos antes de la era cristiana, y Horemheb, general de su antecesor el rey Amenofis IV, en la XVIII Dinastía. 
etruscos, y ésta fue asumida por los historiadores augusteos sin divergencias y de manera generali$\mathrm{zada}^{24}$.

Si bien hoy nadie duda de la veracidad de esa reforma, sí hay serios recelos al adscribirla, tal como se nos describe, al rey Servio Tulio. Los anacronismos son excesivos. Se dan en ella cifras en asses pero no hay asses acuñados hasta tiempos muy posteriores. A mediados del siglo $\mathrm{V}$ muchas transacciones aún se pagaban en especie, y los patricios a los que se pidió que contribuyeran al pago del stipendium tuvieron que aportar cobre, probablemente aes rude, constituidos por piezas metálicas, que llevaron en carros al erario. A principios del siglo III a.C., unas piezas circulares de bronce identificadas como aes grave, tenían el peso fijo de una libra, 327 gramos $^{25}$. En esta situación, se plantean hipótesis sobre el momento en que el sistema pudo realmente estar en funcionamiento.

Las nuevas classes suponían el cambio de criterio sobre los requisitos a la hora de la leva, sustituyendo las tradicionales pautas gentilicias por las de ingresos según censo, de modo que para que todo esto pudiera ser efectivo esta reforma se ha puesto en conexión con la utilización del soldado de tipo hoplita, traído desde Etruria, a fines del siglo V o comienzos del IV. En consecuencia, la reforma censual atribuida a Tulio podrían ser en realidad del siglo IV y aún del III, cuando la centuria ya no desempeñaba en aquel censo una función militar, siendo que a fines de esta última centuria funcio-

24 Liv. 1.42.4; 43; DH 4.16-21; Plut. Sol. 18.

25 Dion. Hal. ant.. 10.50.2; Gell. 11.1.2; Liv. 5.30.3; 52.2; 60.6; Cic. rep. 2. 35.60; Plut. Poplic. 11; Plin. nat. 18.12; 33.43; Festo, p. 237L; 245L; Varro, ling. 5.53, 95; 163; Isid. etym. 16.8.4; Thomsen, R., Early Roman Coinage, Copenhague 1957; Pankiewicz, R., "Quelques remarque sur l'economie prémonétaire dans la Rome archaïque», Acta Classica, 33, 1990, p. 65. Parise, N.F., Dal bue al bronzo. La misura del valore a Roma prima della moneta, Studi Romani, 39.1-2, 1991, p. 92; Mattingly, H., «The First Age of Roman Coinage», JRS 35, 1945, p. 65; Martino, F. de, «Postilla a riforme del IV secolo a. C.», BIDR 80, 1977, pp. 51-53; Crawford, M.H., «The Early Roman economy», $M e$ langes J. Heurgon vol. I, 1976, pp. 197-207, más conservador, afirma que no hubo moneda en Roma hasta el siglo III. Diez mil ases librales a fines del siglo IV eran una fortuna; Momigliano, A., «The Origins», op. cit. p. 93; tipos atribuidos a Tulio, en Gela, Sicilia, Ampolo, C., "Servius rex primus signavit aes", PP 29, 1974, pp. 382-388; Poucet, J., Les rois, op. cit. p. 297; Ridley, R.T., "The Enigma of Servius Tullius», Klio, 57.1, 1975, p. 147; Milne, J.G., «The aes grave of Central Italy», JRS 32, 1942, pp. 28. naba con plena madurez, como vemos de la noticia de Livio sobre los diversos niveles de fortuna en que los ciudadanos se clasificaban, con ocasión de la dotación de marineros y remeros para la flota ${ }^{26}$.

Otra noticia mitiga la sospecha de falsedad de la atribución de esta reforma al rey Tulio. En referencia a un discurso pronunciado por M. Porcio Catón en el 169 a.C., sobre los tiempos antiguos, el tratadista de mediado el siglo II d.C. Aulo Gelio indicaba que el censor citaba una primera estructura centuriada sencilla, que agrupaba en una classis a los ciudadanos de mayores ingresos, en un total de 40 centurias de iuniores, considerando al resto como ajenos a tal organización, y por tanto infra classem. Esta estructura, bastante más simple, estaría vigente en el siglo VI, muy distinta de la que ciertamente mas compleja citan Livio y Dionisio, y que atribuyen a Servio Tulio. Los equites formarían un tercer sector aparte ${ }^{27}$.

26 Val. Max.3.4.3; Gabba, E., «La Roma dei Tarquini», Athenaeum, 86.1, 1998, pp. 11; Mattingly, H., «The Property Qualifications of the Roman Classes», JRS 27, 1937, p. 106; Cornell, T. J., Los orígenes, op. cit. pp. 209 y 216; Nilsson, M.P., «The Introduction of Hoplite Tactics at Rome: Its Date and Its Consequences», JRS 19, 1929, p. 6; Cornell, T.J., "The valuem», op. cit. p. 58: vid. además, Last, H., «The Servian Reforms», JRS 35, 1945, pp. 30-48; para Crawford, M.H., ed., Roman Statutes, II. London 1996, p. 562, Servio Tulio estableció alguna forma de censo; Raaflaub, K.A., "The Conflict», op.cit. pp. 11 y 44, n. 122; Cascio, E. lo, "Ancora sui censi minimi delle cinque classi serviane", Athenaeum, 66, 1988 , p. 275 ; es posible que los analistas se vieran influenciados por las reformas de Solón y Clístenes, con relación a la Roma censitaria de Servio Tulio, J. Poucet, Les rois, op. cit. p. 222; Colonna, G., «Un aspetto oscuro del Lazio antico: le Tombe del VI-V secolo», PP 32, 1977, p. 160.

27 Gell. 6. 13; año 426, Liv. 4.34.6; Festo, 100L; RAAFLAUB, K.A., The Conflict, op.cit. p. 13; RichARD, J.-C., «Patricians and Plebeians: the Origin of a Social Dichotomy», Social Struggles in Archaic Rome. New Perspectives on the Conflict of the Orders, ed. by K. A. Raaflaub, [The University of California Press, 1986], Oxford 2005, p. 115; Cornell, T.J., Los orígenes, op. cit. pp. 222 y 227; GABBA, E., «Proposta per un quadro storico di Roma nel V sec .a. C.», M. Humbert (a cura di), Le dodici tavole. Dai decemviri agli umanisti, Pavia 2005, pp.117-124; Fraccaro, P., «La storia dell'antichissimo esercito romano e l'etá dell'ordinamento centuriato", Opuscula II, Pavia, 1957, pp. 286306; GabBa, E., La Roma dei Tarquini, Athenaeum, 86.1, 1998, p. 8: Momigliano, A., "An Interim», op.cit. p. 120; CornelL, T.J., «The value», op. cit. p. 57; IDEM, «The Rise of the Plebs in the Archaic Age of Rome», Social Struggles in Archaic Rome. New Perspectives on the Conflict of the Orders, ed. by K. A. Raaflaub, [The University of 
Es posible que la noción que la analística consultada por los historiadores augústeos tenía sobre el origen de su asamblea centuriada, una organización plenamente madura y completa respecto a su funcionamiento al menos desde el siglo III, moviera a éstos a remontar sus raíces a los tiempos más antiguos, incluso a los del régimen anterior, adscribiéndola a un rey de origen latino, Servio Tulio, de manera que estas reformas fueran prácticas y desarrolladas desde los primeros momentos de la República. Se adscribió a un rey de origen latino - lo que a fines de la República era como decir romano -, acaso para esquivar el despropósito que para los eventuales lectores de estos relatos supondría tener que asumir que los cimientos de la organización política del estado republicano, habían sido obra del último monarca del régimen, un etrusco y además de siniestro recuerdo.

Se optó por esta versión aún a costa de articular una sucesión de los hechos menos cabal, en la que, en primer lugar, se atribuía a un monarca la sustitución del poder gentilicio, base hasta ese momento del poder de los reyes, por un poder basado en las fortunas según censo, soporte de un régimen que daba el poder a los nobles. $\mathrm{Y}$ en segundo lugar, se adscribía la reforma a un rey, pero no al último, a aquel cuyo legado hubiera podido ser recogido de inmediato por el nuevo régimen que sustituyó a la monarquía. Después de Tulio gobernó otro monarca durante veinticinco años, Tarquinio el Soberbio, el tiempo que las medidas de Tulio tuvieron que esperar antes de hacerse - supuestamente - efectivas, y del que además se nos dice que abolió todas las leyes de Tulio. Para los escritores era preferible esta incoherente versión que atribuirlo a Tarquinio, el rey extranjero, despótico y tirano, que asumió el papel negativo que justificaba el final del régimen. Pero todo esto no pasa de ser una hipótesis de interpretación de los datos ${ }^{28}$.

\section{El testimonio de Claudio.}

Asemás de la tradición sobre el origen latino del rey Tulio otras noticias lo hacen etrusco. Esta percepción pudo fraguarse en los tiempos augústeos, cuando escribieron sus obras Livio, Virgilio, Estrabón, Trogo Pompeyo y con ellos, el joven y futuro emperador Claudio, autor de una historia de Cartago y veinte libros sobre la historia etrusca. Con la

California Press, 1986], Oxford 2005, p. 180.

$28 \mathrm{DH} 4.41 .2 ; 43.1$. apreciable supervisión de Livio y el apoyo literario de un tal Sulpicio Flavo, Claudio pudo tener facilidades para conocer la historia etrusca por sus conexiones con los Urgulanii, la familia etrusca de su primera esposa Plautia Urgulanina, hacia el 15 d.C. y su amistad con Sejano, el poderoso prefecto pretorio de Tiberio, igualmente de origen etrusco, de Volsinii en concreto ${ }^{29}$. A los datos de cuantos dieron alguna noticia sobre Tulio en tiempos de Augusto debemos sumar dos documentos, de interés ciertamente extraordinario por calidad y contenido. Se trata de la inscripción que recoge el discurso que el emperador Claudio pronunció ante el senado en el año 48, en defensa del derecho de los galos a acceder al cursus honorum de la Ciudad, y los frescos murales de la Tumba François de Vulci, fechados en la segunda mitad del siglo IV a.C. La lápida que contenía el discurso apareció en Lyon en 1526, y cuenta con una bibliografía de referencia amplísima, que por no ser prolijos omitimos reseñar. El texto de la inscripción se extendía en dos columnas, afectando la primera al tema que nos ocupa. En ella Claudio afirmaba haber consultado con relación a sus referencias a los tiempos de la monarquía, a autores etruscos que citaban personajes ausentes o al menos marginales en el relato historiográfico romano tradicional ${ }^{30}$.

29 Suet. Claud. 2.2; XLI.1; LEVICK, B., "Antiquarian or Revolutionary? Claudius Caesar's Conception of his Principate», AJPh 99.1, 1978, pp. 80 y 84, n. 14; "el de Cures (Numa Pompilio), luego Tulo, Anco, los Tarquinios y Bruto, el vengador", Verg. aen. 6. 810/817; lo omite Str. 5.2.2, y en 5.2.7, cita a Tulio, fuera de contexto sucesorio, para decir que incorporó dentro de la muralla a las colinas Esquilina y Viminal; Dion. Hal. ant. 3.48.2; Liv. 1.34.5; 10; Zonaras, 7.8.1; Just. 38. 6.7; Hermon, E., «La période royale à Rome: Légende et histoire", Réflexions historiques, 11.3, 1984, p. 315; Tamborini, F., «La vita economica nella Roma degli ultimi re», Athenaeum 8, 1930, p. 300; Martino, F. de, «Storia arcaica e diritto romano privato", Martino, F. de, Diritto, economia e societá nel Mondo Romano, I, Napoli 1995, pp. 387-407; Heurgon, J., Roma, op.cit. p. 161; se piensa incluso que Servio Tulio, figura anormal y atípica, fue un invento tardío, Grandazzi, A., La fondation, op. cit. p. 270; Ridley, R.T., «The Enigma», op. cit. p. 163, n.68; Livio asume tanto la posición de un origen latino como su homologación con lo etrusco, como vimos más arriba, Liv. 2.2.3-5.

30 Oratio Claudii Caesaris de iure honorum Gallis dando, o Tabula Claudiana o Lugdunensis, del año 48 d.C., descubierta casualmente en el año de 1528, en Lyon, CIL XIII, 1668, Fabia, PH., La table Claudienne de Lyon, Lyon 1929; M. Cristofani, Ricerche sulle pitture della Tomba François di Vulci. Fregi decorativi, Dialogi di Archeologia 1, 1967, 186-219; Briquel, D., Le temoignage de Claude 
La pretensión de Claudio era defender el derecho de los nobles galos - primores gallorum - al ius honorum, sobre la base de una tradición secular en Roma de acogimiento de extranjeros, y su incorporación a las instituciones de la Ciudad. Así, citaba a los miembros más antiguos de su propia familia, los Claudios, procedentes de Regilo, con Attus Clausus, a los Coruncanios de Camerio, a los Julios de Alba y a los Porcios de Túsculo. Antes que ellos, se habían establecido en Roma los reyes Lucio Tarquinio, hijo del corintio Demárato, Servio Tulio, hijo de una esclava llamada Ocresia, de Cornículo, y el mismo Numa, procedente de la Sabina. Todos los enemigos de Roma - volscos, ecuos, etruscos, samnitas, senones y otros -, al final, con el paso del tiempo, indicaba Claudio, fueron admitidos en la amistad de Roma, algo que ya empezó a hacer con sabiduría el mismo Rómulo, aseguraba el emperador, al vencer al enemigo y luego incorporarlo. De hecho, Claudio pensaba que esa fue la clave de la decadencia del poderío de lacedemonios y atenienses, que a sus enemigos derrotados, siempre les mantuvieron como extranjeros ${ }^{31}$.

Interesa especialmente el texto de las líneas 20 a 30, col. I, en donde Claudio hacía un breve repaso de la monarquía. En resumen, Claudio resaltaba el origen extranjero de todos los reyes de Roma, y sobre Tulio en concreto, señalaba lo que decían las fuentes etruscas: que había sido el camarada fiel de un tal Caile Vibenna en todas sus aventuras, bajo el nombre de Tuscus Mastarna, Mastarna el Etrus-

sur Mastarna/Servius Tullius, $R P h, 68,1990,86-108$. Interesa aquí la col. I, 16-23: (nam et | hoc inter auctores discrepat) insertus Servius Tullius, si nostros | sequimur, captiva natus Ocresia; Si Tuscos, Caeli quondam Vi | vennae sodalis fidelissimus omnisque eius casus comes, post | quam varia fortuna exactus cum omnibus reliquis Caeliani | exercitus Etruria excessit, montem Caelium occupavit et a duce suo | Caelio ita appellitatus, mutatoque nomine (nam Tusce Mastarna | ei nomen erat) ita appellatus est, ut dixi, et regnum summa cum rei $\mid p$. utilitate optinuit.

31 Sobre el tema, Pareti, L., «Mastarna, Porsenna e Servio Tullio", Studi minori di storia antica, I, Roma 1958, pp. 316-319; HeURgon, J., «La vocation étruscologique de l'empereur Claude", Scripta varia, Bruxelles 1986, pp. 427432; Briquel, D., "Le témoignage de Claude sur Mastarna/ Servius Tullius", BPH 68 1990, pp. 86-108; Simone, C. de, "Latino magister ("capo") etrusco mastarna - macstrna: che ordine di relazione?», RFIC 130.4, 2002, pp. 430-456; FonTANA, G., ¿Maxtarna en la tradición historiográfica romana?.Un intento de reconstrucción de Festo, 486L, Veleia VIII/IX, 1991/1992, p. 444.
$\mathrm{CO}^{32}$, que después, por un golpe contrario de la fortuna abandonó Etruria, con los restos del ejército de este Caile, ocupó el monte Celio, que llamó así en memoria de su jefe, y con el nombre cambiado a Servio Tulio obtuvo el gobierno de Roma, lo que fue de suma utilidad para la República, en opinión del emperador. Pero si creemos a los nuestros, proseguía, entonces Tulio era hijo de una cautiva llamada Ocresia, como recogía Livio. Luego, concluía el emperador, después que el carácter de Tarquino el Soberbio empezó a ser detestado en nuestra ciudad, ya de él, ya de sus hijos, naturalmente el alma del reino se agotó $^{33}$.

32 (nam Tusce Mastarna ei nomen erat) ita appellatus est, col. I. 21-22; El Oxford Latin Dictionary, traduce tusce, en efecto, como "en lengua etrusca", pero considero más adecuada la traducción que, en combinación con Gellio, II.25.8, se obtiene del Diccionario de A. Blanquez Fraile, t. I, pág. 50, primera columna. Gellio cita analogías latinas comúnmente admitidas, con tres casos, osco, graeco y tusco, con la preposición de ablativo delante, "a" o "ab": Item cum dicamus ab "Osco", "Tusco", "Graeco", por"Osce", "Tusce", "Graece", a "Gallo" tamen et "Mauro" "Gallice" et "Maurice" dicimus. Esto es, ab osco, a graeco y a tusco, serían análogos a osce, graece y tusce. Blánquez, en el lugar citado, indica que la preposición "a", con nombre de ciudades o patria, se emplea parea expresar de dónde es uno originario, sustituyendo al adjetivo gentilicio. $\mathrm{Y}$ añade dos ejemplos, pastores a Pergamide, pastores de Pérgamo, y Turnus Herdonius ab Aricia, Turno Herdonio de Aricia. De modo que "a tusco", que es igual a "tusce", debiéramos traducirlo como "etrusco", o "de Etruria", y el texto en cuestión, Tusce Mastarna | ei nomen erat) ita appellatus est, se traduciría por "(el nombre de aquel era Mastarna de Etruria, o el Etrusco), así era llamado". No “en la lengua etrusca”, una extensión libre, a partir de una, a mi juicio, incorrecta interpretación del texto de Gelio, que no habla de nada de esto y se limita a enumerar las analogías.

33 Col. I, 20/25. J. Heurgon, Roma, op. cit. p. 162; Mastarna ocupa el Monte Celio y Porsena, mas tarde, el Janículo y luego la Ciudad misma, Cornell, T.J., Los orígenes, op. cit. p. 177; para Sanctis, G. de, «Mastarna», op. cit. p.102, la identificación de Mastarna con Servio Tulio era hipótesis de Claudio. Se piensa que Tunies es el nombre de una gens de Volsinii, equivalente a Tullius en latín, por lo que cuando Mastarna cambio su nombre por el romano, lo único que hizo fue tomar su antiguo nombre etrusco, transcrito al latín, Laurendi, R., «La monarchia etruca a Roma ed il nomen di Servio Tullio: epos e storia. Dati e considerazioni sulla Tavole di Lione e la Tomba François», Polis, III, 2010, p. 143; pero Claudio consideraba a Mastarna un condottiero etrusco, que ocupó la colina Caelia, Ridley, R.T., "The Enigma», op. cit. p. 163. Los hermanos Vibenna eran unos personajes notorios no sólo en su ciudad, Vulci, sino en otras ciudades etruscas, como en Portanaccio, Veyes, de donde procede un vaso fechado en la primera mitad del siglo VI, que lleva la 
Creemos que Claudio mezclaba la información que decía tomar de los etruscos, con sus propios intereses políticos. No parece conveniente admitir que los autores etruscos identificaran a ese macstrna ó mastarna, que Claudio convierte en antropónimo, agregádole el apodo de tuscus, Mastarna el etrusco, de la misma forma que sería redundante $\mathrm{y}$ desafortunado que a un rey nacido en Roma los propios autores romanos lo identificara con el innecesario apodo de el Romano. Si Mastarna era etrusco, en la tradición etrusca el apodo tuscus sobraba. En consecuencia, tuscus puede ser un añadido de Claudio, para reforzar su propósito, que era manifestar sin dudas el origen extranjero de ese macstrna o Mastarna. Un etrusco, como veremos, no hablaba así de un compatriota, de otro etrusco; de un extranjero, como era un romano, si lo haría. La explicación del nombre de la colina Caelia, en honor de la memoria del camarada de Mastarna, Caile Vibenna, muerto anteriormente, suponemos que en alguna acción militar previa, carece de otra confirmación. Otras noticias sobre presencia etrusca en torno a los alrededores de la Ciudad, alcanzan explicaciones etiológicas como el origen del vicus tuscus, que más adelante veremos, siendo tan verosimiles como la presente. Sobre la tradición latina, Claudio manifiesta que según aquella, Tulio era hijo de una cautiva llamada Ocresia, y por Livio pudo saber que antes y después de éste gobernaron dos reyes de origen etrusco del mismo nombre.

El vocablo macstrna fue traducido por los autores latinos como general, jefe militar, homologable según ellos a magister, aunque desde una perspectiva más exacta, hoy se traduce como un sustantivo común, no referido a persona concreta, la jefatura militar, la comandancia, el mando o estado mayor desde el que se dirige una guerra, dado por el sufijo - rna. De modo que asignado el término a una persona, no lo podríamos considerar como el jefe militar o magister latino, sino aquel individuo que se vinculaba a esa jefatura militar, el aliado o colaborador, la persona asociada a un puesto de mando, lo que por otro lado concilia con el texto que hablaba del personaje como sodalis fidelissimus de Vibenna. Claudio trataba el término igual que la tradición trató el caso de lucumo, del etrus-

inscripción “Avile Vipiiennas me lo dedicó”. Hay también un espejo de Bolsena, de los hermanos Vibenna, y cuatro urnas cinerarias de Chiusi, Poucet, J., Les rois, op. cit. pp. 203/204; Ogilvie, R.M., op.cit. p. 86. co lauchume, el rey, que en latín pasó a ser Lucumón, nombre propio, y finalmente derivó en Lucio, como praenomen de Tarquinio Prisco y luego del Soberbio. De ahí por tanto que podamos inferir que Claudio identificara aquel macstrna primero como un antropónimo, Mastarna, consolidando su naturaleza foránea con el apodo tuscus, como convenía al interés de mostrar a unos senadores reacios a extender el derecho a los honores a los extranjeros, ya que tal paso venía avalado por una tradición hospitalaria de siglos ${ }^{34}$.

\section{Las pinturas de la Tumba François de Vulci.} ConjeTURAS Y EVIDENCIAS.

La tradición daba noticia de dos Tarquinios, por lo que para distinguirlos se asignó al primero el apodo de Priscus, el Antiguo, y al segundo, al que la tradición despreció por su nefasto reinado, el de Superbus, el Soberbio. Ni el Antiguo ni el Soberbio podían figurar como cognomina en la tradición etrusca, porque esos apodos fueron una adición posterior de la analística o de los historiadores que basaron sus obras en ella. En este contexto, es oportuno hacer referencia al segundo documento, ajeno a la tradición analística, que ampliará la interpretación de las noticias hasta ahora analizadas. Se trata de la Tumba François de Vulci, descubierta en 1857 por su arqueólogo Alessandro François, usada entre los siglos V y II a.C, y decorada con pinturas entre los años 340-310 a.C. En las pinturas murales de esa tumba, que son reflejo de una tradición heroica de la ciudad de Vulci, como luego veremos, los personajes nativos no llevaban apodos de origen ni de ningún otro tipo, tal información era innecesaria para identificarlos por sus compatriotas, mientras que los apodos de origen estaban presentes y completaban el nombre de los extranjeros ${ }^{35}$.

34 Festo, p. 355; Liv. 1.34.1-2; 2.14.9; 5.33.3; 33.26.9; Cic. rep.2.14; Serv. aen. 2.278; 5. 560; 8.65; 475; 10.202; Varro, ling. 5.46; 54; Prop. eleg. 4.2.50: Tac. ann. 4.65. El significado de macstrna como nombre común y no propio - la institución y no el personaje - , recuerda la misma trascripción del término celta de vergobretus, la magistratura concreta y no quien la ocupa en cada momento. Vid. Cristofani, M., Lucumones qui reges sunt lingua tuscorum, Archeologia Classica, 43.1, 1991, 553-557; Bernardi, A., La Roma dei re fra storia e legenda, Storia di Roma, 1. Roma in Italia, Torino 1988, 196.

35 Coarelli, F., «Le pitture della Tomba François a Vulci. Una proposta di lettura», DArch. $3^{\mathrm{a}}$ s. I, 2, 1983, pp. 4369; Buranelli F., (a cura di), La tomba François di Vulci, Roma 1987; Andreae, B., "La Tomba François», Forma Vr- 
La tumba consistía en un largo corredor que daba a tres estancias consecutivas, situadas de forma longitudinal, y otras laterales, hasta un total de diez, nombradas por los estudiosos como atrium, tablinum y cellae, de la que interesa especialmente la número III. La decoración estaba sobre todo en el tablinum y en esa cella, cuyas paredes recogían escenas de gran interés documental. El propietario de la tumba encargó la decoración de algunos muros con escenas de gran fuerza dramática y simbólica, que estuvieran a la altura del prestigio y la dignidad de quienes allí se enterraban. En este sentido, el repertorio homérico proporcionaba el material necesario. El artista, conocía bien el catálogo de emociones, dramas e infortunios que envolvían las hazañas y proezas de una epopeya como la Iliada, y extrajo de ésta los temas que le parecieron significativos y a propósito para decorar las paredes de las estancias principales de aquella cripta. En las escenas representadas, el pintor contrapuso a los modelos griegos los personajes extraídos de su propia galería de héroes, los que en la segunda mitad del siglo IV a.C. configuraban la memoria local de Vulci. Con ellos formó simbólicas escenas de una recia expresividad que fueron protagonizadas en tiempos pasados, y que todos conocían, cubriendo de pinturas los muros del atrium, tablinum y la citada cella. La identificación individualizada con el nombre de cada uno de los personajes representados aseguraba la ausencia de equívocos. Como ya dijimos, el autor no añadió cognomen de procedencia a los personajes de Vulci, por innecesario, pero sí a los de fuera ${ }^{36}$.

El pintor distribuyó linealmente temas y personajes, reservando las paredes del lado izquierdo, según se accedía a la tumba, para los personajes griegos, y el derecho para los etruscos. Creemos que las pinturas del ciclo griego están dispuestas para ser contempladas en primer lugar, hasta conectar por el final con las del ciclo etrusco. En ese lado, había varias parejas de personajes destacados en el argumento homérico. Desde el atrium a la cella III se identifica a Néstor, el rey de Pilos, Fénice, la Casandra, que fue ultrajada por Ayax, el hijo de Oileo, Eteocles y Polinices, Sísifo y Anfiarao, Aga-

bis 9(2004)1, pp. 8-57.

36 Incluso más tarde, en el siglo III a.C. para otros, A. Momigliano, A., "An Interim», op. cit. p. 96; Coarelli, F., «Le pitture», op. cit. pp. 43/69. El discurso de Claudio y las pinturas de la tumba François son dos versiones de la misma leyenda, Sanctis, G. de, «Mastarna», op.cit. p. 100; explicación de las pinturas, Ogilvie, R.M., op. cit. p.86. menón y la sombra de Patroclo, Vanth, el demonio alado. Termina la escena con Aquiles sacrificando a un troyano, Caronte, y los dos Ayax, el hijo de Telamonio y el de Oileo, sacrificando igualmente a otros dos prisioneros troyanos por el funeral de $\mathrm{Pa}-$ troclo - Hom. Il. XXIII.108/225 -. El tono general de la escena es ciertamente funesto, pues se trata del negro hado que los dioses reservan al hombre, y no se escatiman expresivas muestras de ello ${ }^{37}$.

En el lado etrusco, el tono luctuoso y desgarrado continúa en la saga definida por las gestas militares que líderes de Vulci, llevaron a cabo en su momento. El relato pictórico presenta igualmente a los personajes por parejas, algunos de ellos relacionados entre sí, coetáneos, pero sin que podamos asegurar que todos ellos fueran protagonistas del mismo suceso, como sucedía en la Iliada, si bien parecen anteriores los que conectan con el tablinum, y posteriores los que figuran al final de la cella. En cualquier caso fueron hechos referidos al tiempo en que Vulci destacó por sus gestas militares en la región, capítulos de la gloria épica de aquella ciudad. Dos de los personajes, el nombrado como Rasce y el que figura junto al término macstrna, aparecen sin el apodo del lugar de procedencia, lo que pudiera permitirnos pensar que aunque no fuesen adversarios, ello no les convierte necesariamente en vulcienses, pues tampoco encajan con el resto de la onomástica etrusca, compuesta de praenomen y nomen, según vemos en los héroes representados en la tumba.

En la cámara siguiente, la cella III, frente al sacrificio de los prisioneros troyanos, el muro derecho presenta el sacrificio de personajes etruscos. El ciclo

37 Ayax, hijo de Oileo, y rey de los locrios, durante el saqueo de Troya, raptó a Casandra, hija de Priamo, del santuario de Minerva donde estaba, lo que causó la ira de la diosa y su castigo, ejecutado por Neptuno. El otro Ayax, hijo de Telamón, disputó con Ulises el quedarse con las armas del difunto Aquiles, y al no obtenerlas, se suicidó, sin que su hermano Teucro le ayudara, por lo que el padre de ambos, Telamón, castigó a éste con el destierro. Célebre adivino y general del ejército contra Tebas, Anfiarao, víctima del engaño de su mujer Erifile, lo que le lleva a la muerte. Sísifo, un embustero que reinó en Corinto, recibe castigo eterno por engañar primero a su mujer, luego a Plutón y finalmente a Mercurio. Eteole, que debe ser Eteocles, y Polinices, hijos de Edipo y Yocasta, reyes de Tebas. Tras expulsar a su padre del reino, se lo disputaron hasta la muerte de ambos; Néstor de Pilos, que condujo a los mesenios a los muros de Troya, rey sabio, prudente y elocuente, famoso por sus buenos consejos, vivió hasta muy viejo en paz. 
histórico etrusco comienza con la escena de un personaje que libera las ligaduras que inmovilizaban las muñecas de otro, identificado con la inscripción de Caile Vibenna. Sobre el liberador figura la identificación como macstrna. Siguen tres parejas de personajes que parecen emular a los troyanos sacrificados del muro opuesto, ofreciendo un sombrío escenario en el que no hay tregua en mostrar que, la efímera gloria humana cede siempre ante la inexorable fatalidad que se cierne sobre el hombre, aquí simbolizada en los adversarios vencidos.

Troyanos y etruscos sacrificados, salvo en un caso, aparecen desnudos, como era habitual en los condenados. Los personajes etruscos representados eran un tal Aule Vipinas - hermano de Caile -, que aparece dando muerte a Venthi Caules [.]plsachs (de Salpino?), un tal Rasce, matando a Pesna Arcmsnas (de Volsini), Larth Ulthes, sacrificando a Laris $\mathrm{Pa}-$ pathnas Velznach (de Sovana?), y ya en el muro que continua en el tablinum, Marce Camitlnas a punto de agredir a otro, nombrado como Cneve Tarchunies Rumach, y que permanece sentado en el suelo. Completaban la hilera las figuras del propietario de la tumba, Vel Saties, y su mujer, Thanchvil Verati, acompañados de un personaje, un tanto orondo y contrahecho, nombrado como Arnza, del que se estima pudiera ser su hijo, o acaso un siervo ${ }^{38}$.

Los cuatro personajes ajenos a Vulci añadían el correspondiente apodo de procedencia. Ya advertimos que el apodo tuscus resultaba incongruente, además de impreciso - ¿de qué ciudad etrusca, de Tarquinia, de Veyes, etc..? -, y que lo más probable es que fuera un añadido de Claudio, esto es, la innecesaria sobrecalificación que haría un ciudadano de Roma a la hora de distinguir al extranjero del que no lo era. Un ciudadano de Vulci o de Tarquinia no se identificaría entre los suyos como etrusco sino como vulciense o tarquiniense, siendo el cognomen tuscus o etrusco, el que usaría más un individuo ajeno a ese pueblo, como un latino o un romano, por ejemplo.

38 Poucet, J., Les rois, op. cit. pp. 100-112; Ridley, R.T., "The Enigmaw, op. cit. p. 165, piensa que Mastarna es uno de los capturados, que una vez rescatado, libera a los demás. La tumba, en Laurendi, R., "La monarchia etrusca», op. cit. p. 130. Otra interpretación hablaba de una liberación de Caile Vibenna, cautivo de Tarchunies Rumach, a cargo de Aule y macstrna, siendo el romano finalmente ejecutado por Marce Camiltnas, Scullard, H.H., op. cit. p. 30, sin que conozcamos como llegó a tal conclusión.
En la pintura, el tal macstrna o Mastarna es alineado con los héroes de Vulci, porque gracias a su diligencia un personaje de la ciudad, Caile Vibenna, fue liberado del enemigo que le tenía preso. Como anteriormente analizamos, el término macstrna definía una jefatura o comandancia militar, por lo que al señalar con ese término al personaje liberador, el pintor probablemente pretendía identificar a un individuo que no era de Vulci y cuyo nombre el paso del tiempo podía haber borrado. Es posible que al tratarse de antropónimo ajeno a la lengua etrusca, el término fuese de difícil pronunciación y recuerdo para un etrusco, y se perdiese - como Plin. nat. III. 28; 118, señalaba con los etnónimos astures -, siendo suficiente la mención de su hazaña con el personaje etrusco para que cualquier vulcitano recordara su ayuda eficaz y valerosa en momentos puntuales de las gestas de uno de sus héroes más conocidos $^{39}$.

Claudio debía conocer la versión de Livio sobre los reyes romanos, pero se interesaba más por la etrusca, porque venía mejor a sus intereses en ese momento, que era mostrar a los senadores que los extranjeros, incluidos los etruscos, sus enemigos durante muchos años, fueron acogidos en Roma llegando incluso a ser reyes. En su tiempo, con varios siglos de un Lacio dominado y y perfectamente integrado políticamente en la Ciudad, no era argumento de peso ante unos senadores reacios, mostrar la capacidad de acogida de la Ciudad mencionando a alguien, por ejemplo, de Cornículo, como la tradición decía de Servio Tulio. Nadie de esa villa era ya en el siglo I d.C. suficientemente extranjero. Ya al principio de su discurso tuvo que subrayar que el rey Numa, aunque era de los sabinos, región en su tiempo considerada ya como poco más de una mera extensión de Roma, en aquel entonces era un extranjero, ut Numa ... ex Sabinis veniens, vicinus quidem, sed tunc externus, col. I.10. En cambio, una patria etrusca, con lengua y cultura propias, no

39 Un personaje muy brillante en la guerra, natural de la ciudad latina de Solonio, a unos $32 \mathrm{kms}$. de Roma, se llamaba Lucumón y estaba al frente de los mercenarios tirrenios que ayudaban en la guerra a Rómulo, de quien era amigo, Dion. Hal. ant. II.37.2; 42.3; 43.2. Se cita otro Lucumón, hijo de Arrunte de Clusio, que en el 391 trajo a los galos a Etruria, Plut. Cam. 15; Liv. 5.33.4; la palabra mastarna aparece en un sarcófago de un magistrado como título, según M. Pallottino et alii, Thesaurus Linguae Etruscae, Roma 1978, 195, y en latín es magister populi, según RiDLEY, R.T., "The Enigma», op. cit. p. 165. 
necesitaba de otros elementos de persuasión, por lo que sabiendo que tras el reinado de un etrusco como L. Tarquinio reinó un latino de nombre Servio Tulio, aquel personaje al que nombraban como macstrna, que según los autores etruscos se instaló en el Monte Celio, tras la muerte de su camarada Caile Vibenna, y que más tarde se apoderó de la Ciudad, no podía ser más que Servio Tulio. La conversión del vocablo etrusco en antropónimo, y el cambio de nombre al acceder al trono, participaba de la misma etiología del precedente de Lucio Tarquinio, antes lucumo/Lucumón, que resolvía el problema ${ }^{40}$.

La tradición romana ignora cualquier suceso relacionado con Vulci, pero recoge alguna noticia sobre los Vibenna. A principios de siglo II d. C., Tácito aludía al origen del nombre del Monte Celio, que según él, antiguamente se conocía como Monte Querquetulano, por su abundancia en encinas, y lo vinculaba igualmente a Caile Vibenna, caudillo del pueblo etrusco que tras haber ayudado a Tarquinio Prisco, recibió de éste aquel lugar, o de cualquier otro de los reyes, pues, añadía, aquí disentían los historiadores. El recuerdo de aquella información era ya tan vago en el siglo II d.C., que Tácito no puede asegurar si aquel caudillo etrusco estuvo con Prisco, o con Rómulo, casi dos siglos antes. La versión que lo vinculaba a Rómulo justificaba su labor como mercenario contra el rey albano Tito Tacio, o contra los sabinos, tras el rapto de sus mujeres por los romanos ${ }^{41}$.

Lo que se sabía con certeza, aseguraba Tácito, es que aquellas tropas etruscas se asentaron en las llanuras cercanas al foro, de donde le vino el nombre

40 De los etruscos, resaltaba Liv. 1.40.2, que ni siquiera eran itálicos. Sanctis, G.de, "Mastarna», op. cit. pp. 100 y 102; para Cornell, T.J., Los orígenes, op. cit. p. 172, Tulio y Mastarna fueron dos personajes diferentes. El floruit de este Servio/ Mastarna se sitúa en el tiempo de Tarquinio Prisco, Cazanove, O. de, La chronologie, op. cit. p. 630. Para Gantz, T.N., «The Tarquin», op. cit. p. 554, L. Junio Bruto pudo ser nieto de este Cneo Tarquinio Romano. Debemos recordar que una tradición verídica puede conservarse un máximo de siglo y medio, Poucet, J. Les rois, op. cit. p. 90.

41 Tac. ann. 4.65; Dion. Hal. ant. 2.36.2, cita a un Celio etrusco que dio nombre a la colina, pero en tiempos de Rómulo. Mastarna no puede entenderse como una etrusquización del título magister, como es de opinión común, sino que el sufijo etrusco - na puede significar perteneciente o ligado al magister", lo que nos estaría hablando de una subordinación, alguien que actúa en colaboración con el jefe, Laurendi, R., La monarchia etruca (cit. n. 40) p. 144. Para Martinez-Pinna, J., "Tarquinio», op. cit. p. 259, Aulo Vibenna era el jefe, por encima de su hermano Caeles. de vicus tuscus a aquel paraje, por la procedencia de aquellos extranjeros. Según Festo, que acaso toma la información del liberto erudito augústeo Verrio Flacco, todos los etruscos que de una forma u otra llegaron a Roma - los Vibenna, el nombrado macstrna o Mastarna, el rey Porsena -, acabaron dando nombre a la zona que ocuparon, vicus tuscus. No se hablaba de una ocupación violenta de la colina, sino de una especie de compromiso, una cesión por parte del gobierno de Roma, lo mismo que en otro lugar se atribuirá a Porsena y de nuevo más tarde, en cuanto supone una cesión, cuando se justifica la salida de los galos que tomaron la Ciudad en el 387 a.C. Este modelo de explicación no era ajeno a las prácticas llevadas a cabo frecuentemente tras acontecimientos bélicos en la historia de la República. Recordemos por ejemplo los asentamientos de tropas mercenarias con consentimiento previo o no de los propietarios de las tierras afectadas, como el caso de los mamertinos, mercenarios campanos asentados en el Nordeste de Sicilia, desde que sirvieran a Agatocles de Siracusa, entre fines del siglo IV y principios del III, y que acabarían gobernando en Mesina durante veinte años ${ }^{42}$.

42 Str. 5.2.2, convertía a Porsena de Clusio en aliado de los romanos, que celebraron su nueva relación de amistad con quien poco antes había sido su enemigo. El geógrafo omite cualquier referencia al reinado de Servio Tulio. Mastarna ocupó la colina Celia durante el reinado de Tarquinio Prisco. O sea, en 617/579 a.C. Tac. ann. 11. 23-24; 25.1; Liv. 1.35.3. Para Poucet, J., Les rois, op. cit. pp. 195 y 207, Mastarna era un etrusco de Vulci que se instala en Roma como rey; Liv. 1.39/41: Dion. Hal. ant. 4.3; 7; Mastarna, el futuro Servio Tulio, no era etrusco sino latino, Martínez Pinna, J., "Tarquinio", op. cit. pp. 273/286; Bianchi, L., "Il magister», op. cit. p. 8; en otra interpretación de las pinturas, Aulo Vibenna y Mastarna pelean juntos contra Cneo Tarquinio, para liberar a Caeles Vibenna, prisionero del romano, Sanctis, G. de, "Mastarna», op. cit. pp. 98-99. La participación de Aulo junto a Mastarna en la toma de la Ciudad encuentra un supuesto respaldo etimológico: Aulo = Ole u Olus, formaría parte del término Capitolio, caput-oli, la cabeza de Aulo, por lo que el líder etrusco estaría enterrado en aquella colina, qui ignoret Oli ese sepulcrum Vulcentani, Arnobio, adv.nat.6.17. Aulo fue enterrado en el Capitolio porque no podía serlo en su ciudad, ya que debió ser expulsado de ella por algún delito, Ridley, R.T., "The Enigma», op. cit. p. 165. Buen número de ciudades de Sicilia estaban cajo el control de mercenarios, en el siglo IV, y Sardinia tenía asentamientos de ellos, Polib.1.79.1; Plut. Tim. 1. 


\section{RETÓRICA, ARQUETIPOS, ANACICLOSIS}

Desde el análisis retórico, la exposición de Livio se ajustaba a las formas del discurso. Su relato introducía los conceptos o ideas de manera correcta, otorgando la disposición adecuada - uno de los cinco elementos de la Retórica - a cada una de las partes en su lugar, algo en lo que, según Cicerón, $\mathrm{M}$. Antonio, el cónsul del 99, era un experto. Así, cada uno de los personajes, como el rey Tulio, los dos Tarquinios, el cónsul L. Bruto, o más tarde las dos comisiones decenvirales, asumía las funciones que les correspondían. El historiador patavino podía saber por los tratados retóricos al uso, que la manera más segura de ganar el ánimo de los oyentes - lectores, en este caso - era, hacia el lado del rechazo, suscitando el odio, la animadversión o el desprecio contra los personajes perniciosos, los adversarios, atribuyendo y describiendo la inmoralidad, arrogancia, perfidia, crueldad o fraude de sus actos; subrayando su carácter violento, sus intrigas, su poder excesivo, sus riquezas desordenadas, y en definitiva su conducta depravada. Con estos caracteres se elaboró la imagen del Soberbio, y unos decenios después la de Apio Claudio, cuando presidió la segunda comisión decenviral, o la de Sexto Tarquinio, el hijo de aquel, o los dos Herdonios, Manlio Capitolino, o los Espurios Casio y Melio, entre otros ${ }^{43}$.

Livio utilizó las fórmulas retóricas necesarias para construir un discurso que hiciera verosímiles y justificados los cambios constitucionales. No olvidemos que era un recurso retórico lícito para quienes escribían sobre historia, el faltar a la verdad, si con ello se lograba ser más impactante en la exposición ${ }^{44}$. Así, siguiendo el modelo de evolu-

43 it igitur, ut supra significaui, diuisio rerum plurium in singulas, partitio singularum in partis discretio, ordo recta quaedam conlocatio prioribus sequentia adnectens, dispositio utilis rerum ac partium in locos distributio, Quin. Inst. 3.3.1; 7.1.1-2; 9.2.2-3; Diod.5. 1.4; Cic. Brut. 139; de orat. 2.203; inv. I.9; Ret. Her. 1.8; 5.47; incluso algunos autores elogiados merecieron reproche por no haber realizado una equilibrada distribución de las partes de su material, Diod. 5.2; Momigliano, A., "The Origins» (cit. n. 10) p, 93; Lewis, D.M., «The tyranny of the Pisistratidae», CAH IV, \{1988] 2008, pp. 287. Para los autores clásicos el discurso forense y la historia tenían muchos rasgos en común, pero el fondo de cada uno era diferente, Cic. Orat. 66; Plin. ep. 5.8.9. "(Una historia general) exige un máximo cuidado en la composición y distribución de la materia, para que la ordenación de nuestra obra resulte inteligible tanto en los detalles como del conjunto", Polib.5.31.7.

44 Cic. Brut. 42. ción de las constituciones, la monarquía dio paso a la República por la conducta tiránica e injusta del último rey, y se ofrecían como causas, además de las que eran de esperar de un tirano, otras que afectaban a su familia - conjurando así la posibilidad de un traspaso de poderes dentro del clan -, como la violación de Lucrecia por Sexto, hijo del monarca expulsado. A las causas familiares, se sumaba el daño infligido a todos los sectores de la población romana. Sesenta años después, los segundos decenviros fueron juzgados y desposeídos de sus poderes para que se reinstaurara el consulado, tras más de un año de gobierno tiránico, en los que no hubo justicia sino terror y sufrimiento para los ciudadanos, con episodios como el de Verginia, de sólida analogía con el de Lucrecia.

Otros modelos de conducta podían ser positivos y presentarse como ejemplarizantes y constructivos, pasando entonces a ser arquetipos de alto contenido ético para los lectores. De esta forma, los historiadores augústeos entendieron que era más didáctico e instructivo construir biografías de perfil nítido y esencial, tanto en bondad como en maldad, desglosando de las biografías individuales los actos positivos de los negativos. Así, algunos personajes podían ser presentados con una trayectoria de sujetos básicamente honestos y bondadosos, de gran pericia guerrera, fervor religioso o habilidad social, lo que podríamos resumir como poseedores de aquello que generaba una activa empatía hacia la mayor parte del cuerpo social, para el que se constituía como patrón moral de comportamiento. O por el contrario, podían describir una naturaleza cruel y despótica, ajena a la equidad y la justicia, creando el correspondiente arquetipo, homologable al del tirano griego. El escritor podía igualmente atribuir tales caracteres antagónicos sin mezcla a dos personajes distintos, ofreciendo dos modelos, cada uno representativo de su condición, ya fuese positiva o negativa, sin considerar obstáculo que en realidad ambos patrones de conducta se hubiesen dado simultáneamente en un solo personaje en diversas fases de su biografía ${ }^{45}$.

La transición de Servio Tulio a Tarquinio el Soberbio para algunos, recuerda la de Solón a Pisístratos, el paso del gobernante legal al tirano, aunque el

45 la Antigüedad están llena de actos ejemplares, de retratos inspiradores, y la historia era el instrumento que los mostraba a la luz, Liv. praef. 10; Cic., pro Arch., 15; de fin. 5. 64; fam.5. 12.4; Liv. praef.; Dion. Hal. ant.1.1.2-4. 
tirano romano no gozó de la buena fama que por el contrario tuvo Pisístratos, por la paz y el desarrollo económico que su gobierno supuso para la Atenas de su época. Los actos de injusticia y crueldad de Tarquinio el Soberbio culminaron con el episodio de la violación de Lucrecia, que cerraron cualquier eventualidad de cambio político que no significara la sustitución del régimen. Según la historiografía tradicional, el Soberbio odiaba a patricios y plebeyos, destruía y violaba leyes y costumbres, su reinado fue una tiranía. Duro, cruel, de aspecto terrible, tomaba aquel rey sus decisiones según su humor, no según la justicia y las leyes, de las que abrogó especialmente las aprobadas por su antecesor, no dejando siquiera las tablas en que estaban escritas, ordenando que fueran descolgadas del foro y destruidas ${ }^{46}$.

De esta manera, se distinguía un rey etrusco bienhechor, eficaz y respetuoso con el pueblo, L. Tarquinio Prisco, de otro infame, cuyos actos y los de su familia exasperaron a los ciudadanos, de modo que quedaba justificada su expulsión y la sustitución del régimen ${ }^{47}$. En ambos casos, una transparente biografía era caracterizada por los aspectos positivos de uno y los negativos del otro, que el historiador les asignaba casi sin mezcla. Naturalmente, la credibilidad y verosimilitud se lograba presentando ambos modelos sin una nitidez absoluta,

46 Caracterización del tirano griego, Poucet, J., Les rois, op. cit. p. 253.; Dion. Hal. ant. 4 41.2; 43.1; 4.4; Liv. 1.49.1-7; 53.1. El Soberbio justificaba su toma del trono, por los crímenes de su antecesor, Liv. 1.47.9/11.

$47 \mathrm{El}$ primer Tarquinio, un hombre rico y generoso, amable y de trato cordial, que alcanzó buena reputación entre los ciudadanos, Liv. 1.34.11-12; 1.35.5; 35.9; 37.6; 38.3-4; 38.6-7; 1.57.10. El fin de la tiranía, Cic. rep. 3. 32.44; Liv. 3.43 ; 44/50; 3.51. El propio Liv. 1.42.4-5 es consciente de esta distribución de roles: Numa, creador del derecho religioso, Servio Tulio, creador de la ordenación política y de las clases, con el censo, institución muy saludable para la futura grandeza del Imperio. Tarquinio el Soberbio conspira contra su suegro el rey Servio Tulio y es responsable indirecto de su muerte, y de que no recibiera sepultura. Reina sin mandato popular ni ratificación de los patres, se burla de los latinos al convocarles a una reunión y no comparecer hasta el anochecer. Pero aunque fue un rey injusto en la paz, aquí el historiador hace una concesión, no fue un mal general, Tomó a los volscos Suessa Pometia y los cuarenta talentos del botín los reservó para la construcción del Templo de Júpiter. Su esposa y sus hijos fueron desterrados. Los tres últimos reyes responden al prototipo helénico del fundador, el reformador y el tirano, POUCET, J., Les rois, op. cit. p. 254. Todas las constituciones acaban degenerando, Polib. 6.3/4. esto es, sin la pureza plena de una conducta completamente positiva o una completamente negativa, pues tal circunstancia no se daba en la naturaleza. Este planteamiento se repetirá medio siglo después, con una comisión decenviral propicia y bienhechora, que elaboró las leyes que serían la fuente del derecho, y otra comisión dañina e inicua, que además de aprobar leyes tan inaceptables como la del matrimonio mixto, se hizo cruel y odiosa por su tiranía para la mayoría de los ciudadanos, que lograron su abrogación, para poder así, cambiando el régimen, volver al consulado ${ }^{48}$.

\section{El tRÁNSITO A LA RepÚBLICA}

La tradición aseguraba que ocho años después de la expulsión del Soberbio, la influencia etrusca en Roma y el Lacio siguió siendo grande. Prueba de ello fue que la liga de ciudades latinas mantuvo su apoyo al rey expulsado hasta su derrota en el 495, y que durante ese tiempo varios miembros de familias etruscas alcanzaran el consulado, lo que contrasta con la unidad y cohesión nacional con la que supuestamente la Ciudad se enfrentó a las pretensiones del rey depuesto. Un primer encuentro bélico del que el etrusco sale derrotado, tiene lugar entre el 507 y 506 a.C., tras el cual el Soberbio se retirará a casa de su yerno el noble Octavio Mamilio, en Túsculo. Cinco años después, en el 501 la liga de

48 Los romanos se libraron del último Tarquinio no porque fuera etrusco sino porque fue un tirano, Cornell, T.J., Los orígenes, op. cit. p. 266. Ob superbiam regiam, Liv. 4.15.4; Cic. rep.2. 36.61; 37 62-63; Tab. XI 1; los dos Tarquinios, sólo uno, Gjerstad, E., Early Rome, op. cit. pp. 193-202. Recurso retórico paralelo a lo que estamos describiendo fue el de la concentración. En los fenómenos de concentración el escritor tiende a atribuir a una misma persona todas las creaciones significativas - fenómenos de concentración - de una misma esfera, J. Poucet, Les rois, op. cit. p. 367. Esto lo podemos transferir a la Grecia de los legisladores, por ejemplo: todas las leyes importantes de un pueblo, obra de un solo hombre. El nefasto retrato del Soberbio gana credibilidad al mitigar los aspectos negativos con su papel como militar. Hizo tratados de amistad con hérnicos y algunas ciudades de los volscos, Atacó y asedió Suessa Pometia, de los pomptinos, o de los volscos, como ya hizo Prisco. Los 40 talentos de plata - - o el diezmo en Dion. Hal. ant. 4.50.4; 59.1 - del botín, lo reservó para la construcción del Templo de Júpiter. Sometió Ereto y Fidenas, de los sabinos, Guerra de siete años contra la latina Gabios, Dion. Hal. ant. 4.49.1; 50.2/3; 51/52; 52.3/53.1; 57.4; Str. 5.3.4; Liv.1.48.3; $49.1 ; 49.4 ; 50.2 ; 53.1-3 ; 58.2 ; 59.10-12 ; 53.1$; funda Signia y Circeios, Dion. Hal. ant. 4. 63; Richard, J.-C., «Patricians and Plebeians», op.cit. p. 115. 
treinta ciudades del Lacio conspiraba contra Roma, bajo el liderazgo de este Octavio Mamilio y como se sospechaba que el cónsul Tito Larcio, era de la facción de los Tarquinios, factio Tarquiniana, para enfrentarse a él se pensó en nombrar a un dictador ${ }^{49}$. En el 495 a.C., los latinos, guiados por Mamilio y Tito Tarquinio, hijo del Soberbio, pues sus otros dos hijos, Arrunte y Sexto ya habían muerto, son derrotados en Lago Regilo, en Túsculo, por el dictador A. Postumio Cominio. Con esta derrota de los latinos la fuente concluye la guerra contra el tirano, catorce años después de su expulsión. El rey, que parece que, con las cautelas ya comentadas $s u$ pra, sobrepasaba los 90 años, se exilió en la Cumas de Aristodemos, y murió al poco ${ }^{50}$.

Paralelamente, en un episodio sin clara conexión con esta guerra, en el 508 un jefe etrusco, que las fuentes identifican como Porsena de Clusio, se asienta en el Monte Janículo y desde allí pasa luego a Roma, que captura. La tradición, que explica de manera poco satisfactoria su presencia como apoyo a Tarquinio, subraya que nunca antes hubo tanto miedo en el senado, tantus terror, tal era la fama del poder de Clusio y de Porsena. La ocupación de la Ciudad tuvo una duración que desconocemos, pese a que los textos se inclinen por ignorarla o a reducirla al tiempo de sacar beneficios de su victoria. Tras ésta, según la tradición, por causas no bien explicadas, el etrusco abandona la Ciudad y regresa a su patria. En cualquier caso no sin antes imponer a los romanos en el tratado que firmaron la condición de que sólo usarían hierro para tareas agrícolas, la devolución de unas tierras tomadas antes a Veyes, y que dejasen en libertad a los prisioneros a cambio

49 Porsena, otro tirano, Dion. Hal. ant. 5.21.1; Liv. 2.15.7; 18.3-4; 21.3; FAZıo, M., «Porsenna e la società di Chiusi», Athenaeum 88.1, 2000, p. 398. Se consideran familias etruscas los Aternii, Cominii, Herminii, Volumnii, Aebutii, Licinii, Sicinii, Sempronii, Menenii, Poetelii y Larcii, OgiLvie, R.M., op.cit. p. 51. Dieron siete cónsules, los del 506, Espurio Larcio Rufo y T. Herminio Aquilino, el del 503, Agrippa Menenio Lanato, el del 501 Postumio Cominio Aurunco y T. Larcio Flavo o Rufo, éste mismo de nuevo en el 498, y del 497, A. Sempronio Atrratino; GJERSTAD, E., Early Rome, op.cit. p. 82, habla de diez cónsules etruscos entre el 507/490 y cinco entre 463/442, que corresponderían al tiempo de ambos Tarquinios, según su cronología, y el tiempo intermedio, a Servio Tulio.

50 Liv. 1.60.2; 2.6.9; 19.4; 21.5; 31.3; Dion. Hal. ant. 4.7.3; 6.21.2-3. De ser cierta tal edad, debió comenzar a reinar ya próximo a los 50 años. CoRNELL, T.J., Los orígenes, op.cit. p. 192; RAAflaUb, K.A., «The Conflict», op. cit. p. 16; POUCET, J., Les rois, op. cit. p. 213. de los tránsfugas. Unas condiciones de vencedor, ciertamente humillantes para los vencidos, los romanos, por lo que fue versión que a los analistas parece que les costó asumir y prefirieron otra más patriótica, maquillando todo el suceso.

Sin poder negar la existencia del ataque y la toma del Janículo, en la tradición, salvo alguna excepción, no se menciona de manera expresa la captura de la Ciudad por el de Clusio. Porsena es presentado como un gran adversario que no pudo al final entrar en Roma, y tras ser derrotado su hijo Arrunte, al que había enviado a tomar Aricia, por los de esta ciudad y sus aliados de Cumas, tras dos años de guerra, el rey etrusco decidió levantar el campamento y marcharse. Pese a todo, antes de partir, indica el relato que Porsena pidió al senado que permitiera al Soberbio su regreso como rey, un añadido ciertamente inverosímil, pero que el relato necesitaba señalar para subrayar con la negativa del senado el rechazo al tirano. El desenlace final escapa igualmente a toda lógica. Pese a la reciente guerra que los etruscos Porsena y su hijo Arrunte de Clusio acababan de mantener con Roma, éstos pusieron fin a su enemistad con Roma, dice la fuente, y se convirtieron en sus aliados al recibir honores y pingües regalos. Por ello, Roma les asignó como residencia una zona que había entre el Palatino y el Capitolio, que por ello se llamó desde entonces vicus tuscus ${ }^{51}$.

51 Un Porsina, rey de Volsinii, Plin. nat. 2.140; 34. 139; 36.91; Val. Max.3.3.1, Zilaz purzene. Magistratura suprema. Poucet, J., Les rois, op.cit. p. 228; sobre Porsena, Tzetzes, chil. 6. 201-203; Ampelius, mem. 39.3; 45.1; Cic. Sest. 48; Att. 9.10.3; parad. 1.12; Festo, 355; Floro, epit. 1.4; Liv. $1.34 .5 ; 34.10 ; 2.9 .1 ; 2.11 .1 ; 12.6 / 7 ; 13.4 ; 14.5 ; 15.1-7 ; 2.14 .8-9$; 6.40.17; 98.11.6; per. 2.15; Tac. ann. 3. 72; Str. 5. 2. 2; Dion. Hal. ant. 3.48.2; 5.21; 28.2; 36.3-4; Plut. Public. 16/19; OGILvIE, R.M., op.cit. pp. 86/88; FAZIO, M., Porsenna, op. cit. pp. 399 y 401; CoRNell, T.J., Los orígenes, op.cit. pp. 177 y 258. Zonaras, 7.8.1; para otros, este vicus tuscus fue el barrio de los soldados de Caeles Vibenna, Polib. 6.11A, cf. Cic. rep.2.19; Tac. ann. 4.65. Sin rastro ya de esta hospitalidad y deferencia en el episodio de la derrota de los galos ante Caere, ni cuando años más tarde Roma castigó a esa ciudad etrusca por haber apoyado a la rebelde Tarquinia en una guerra, Liv. 5. 39.9; 40.5-6; 47; 48.8-9; Dion.Hal. ant. 13. 6.1; 7.1-2; 9.1; 12.2; Just. 6.6.5; 12.3-4; Tac. ann. 11.23; Silio, pun. 1.525 ss.; Plut. Rom. 29; Cam.22; Plin. nat. 3.57, Gell. 5.4.3; 17.21.22; Polib.1. 6.2. Esa zona entre el Capitolio y el Palatino albergó el foro y el comitium, cuyo primer pavimento no fue anterior al 575, o hacia el 600, GJERSTAD, E., op.cit. p. 89; CoARelli, F., "La crescitá urbana di Roma. Civiltá dei romani”. La cittá, il territorio, l'impero, Milano 
$\mathrm{Ni}$ los textos ni la arqueología permiten afirmar que el Lacio fuera sometido a una dominación etrusca, en el sentido tradicional del término. El testimonio de Livio no es el de una Roma conquistada por los etruscos por las armas, comparable al que años después sufriría con los galos. Parece por tanto que, con la evidencia literaria disponible, no podemos hablar de una dominación consecuencia de una invasión y de una guerra previa, como ya concluimos supra cuando hablábamos sobre los reyes etruscos, lo que no obsta para constatar la realidad de la presencia cultural de Etruria en la Ciudad como una innegable realidad, de la que sólo se necesita precisar los canales por los que tal legado llegó a las instituciones de la República. Es verosímil la hipótesis de una infiltración pacífica de etruscos, constante y prolongada en el tiempo, como existió de griegos del sur y de otros pueblos, de la que la llegada a Roma a fines del siglo VII de aquel hijo de Demárato, el comerciante corintio, sería una noticia simbólica. Esta infiltración dejó su huella en los ámbitos económico, social e institucional y duró más de dos siglos, a menos hasta la toma final de Veyes, a principios del siglo IV a.C. ${ }^{2}$

Si tomamos la cerámica de figuras negras como prueba de la prevalencia de una u otra ciudad etrusca con relación a Roma, a mediados del siglo VI el $40 \%$ de la cerámica de figuras negras encontrada en yacimientos etruscos procedía de Vulci, seguida de sólo un 25\% para Caere, similar a la cerámica etrusca encontrada en el yacimiento del templo de San Omobono, del Foro Boario, en Roma. De aquí podría interpretarse que la sucesión de líderes etruscos en la Ciudad podría ser consecuencia de la sucesión

1990, p. 17. Para Heurgon, J., Rome, op. cit. pp. 263/264, fue Porsena quien expulsó al último Tarquinio. No hubo un acercamiento de esta clase hacia el rey malo, el Soberbio.

52 Interesa la reflexión de BlakewaY, A., "Demaratus, op. cit. p. 149, "the blood of a king may do but little to influence the culture of a people. It is more important that Rome's subjection to Etruria at this period meant subjection to a people half-hellenised and in constant contact with Greek influence". La arqueología confirma influencia etrusca a partir de la fase Lacial IVB, 630/580, correspondiente a Tarquinio Prisco, Grandazzi, A., La fondation, op.cit. p. 323, y tampoco puede desdeñarse el texto de Catón, que habla de una Italia en otro tiempo en poder de los etruscos, Catón, fr. 62P. Desde la llegada de los eubeos a Pithecusae, Ischia, la influencia griega tanto en Etruria como en Roma es enorme y está arqueológicamente muy documentada, de modo que aunque pueda resultar duro, la mitología griega y romana crecieron juntas, WISEMAN, T.P., «Roman Legend and Oral Tradition», JRS 79, 1989, p. 131; de las diferentes hegemonías de las ciudades de las que procedían. Así, primero habrían sido los reyes de Tarquinia, con Tarquinio Prisco, luego los de Vulci, si seguimos a Claudio, con aquel macstrna, Servio Tulio, o incluso aquel Marce Camiltnas, que sometió a Tarchunies Rumach, y finalmente, que sepamos, Clusio con Porsena ${ }^{53}$.

Creemos que la presencia etrusca en el Lacio fue resultado de conexiones políticas, de alianzas matrimoniales entre las familias que controlaban el poder en las ciudades, sin negar una presión también de los etruscos sobre los latinos, para ponerlos a servir a sus intereses. Pero desde fines del siglo VII, con los intereses económicos ya aludidos y la afluencia constante de extranjeros a las colinas, la Ciudad pasó también a ser objetivo, como otras ciudades, de los proyectos militares de líderes y jefes etruscos y latinos, especie de profesionales de la guerra, de los que conocemos algunos nombres - macstrna o Mastarna, Porsena, los Vibenna -, algunos de los cuales llegaron a gobernar la Ciudad, sin forjar una dinastía, en desacuerdo con lo que informa la tradición. Tal escenario pudo ser la tónica general a lo largo del siglo VI e incluso en tiempos posteriores, pese a lo cual, y como de forma expresiva expondría antaño J. Heurgon, podría decirse que esa Roma gobernada por etruscos de forma discontinua durante una centuria, mantuvo su perfil de una ciudad latina, cuyos habitantes hablaban latín ${ }^{54}$.

La transición política de la monarquía a la República fue pues, un suceso confuso, descrito de manera escueta, en correspondencia con la ausencia de una información fiable que los autores pudieran manejar, y desacorde en los dos principales historiadores que trataron de ello. La realidad es que este

53 Homo, L., Primitive Italy, London 1927, p. 115; Heurgon, J., Roma, op.cit. pp. 159 y 162; Gantz, T.N., "The Tarquin», op. cit. p. 539; Hus, A., Les siécles d'or de l'histoire étrusque (675-475 avant J.-C.), Bruxelles 1976, pp. 219, 225 y 228. Lo que los líderes etruscos pudieron tomar como dominio a fines del siglo VII - 626/600 a.C. - podía estar muy cerca de esa descripción que habla de un mero agregado de grupos de cabañas, con una organización bastante laxa, en la que primaban los intereses gentilicios por encima de los comunales, Martinez-Pinna, J., Tarquinio, op.cit. p. 87; Heurgon, J., Roma, op.cit. p. 162. Desconocemos si la sumisión o muerte de aquel Tarchunies Rumach supuso un gobierno en Roma de su dominador, Marce Camiltnas de Vulci.

54 Heurgon, J., Roma, op. cit. p. 158; o bilingüe, OgILVIE, R.M., op.cit. p. 50; Roma no fue una ciudad etrusca, T. J. Cornell, op.cit. p. 207. 
tránsito es despachado por la tradición en apenas unas líneas, unas breves observaciones para confirmar que la Ciudad pasó del viejo al nuevo régimen. Para Dionisio, el senado expulsó al último rey y estableció el nuevo régimen, con ayuda de la plebe. En compensación, como los plebeyos estaban en inferioridad ante los patricios en los juicios, uno de los nuevos magistrados, los cónsules, dio una ley por la que los plebeyos podían a apelar ante el pueblo sus decisiones, (lex Valeria de provocatione del 509). El nuevo régimen seguía actuando a través de los nuevos magistrados en realidad como hacían los antiguos reyes, pero el poder se repartía ahora entre aquellos, que además eran dos y veían limitado su tiempo de gestión a un año. En Livio además, todos los reyes fueron buenos menos el último, que fue un tirano y como tal, corrió la suerte de los tiranos, por lo que fue expulsado, lo que llevó a cabo L. Bruto. Un adverbio es suficiente para separar el tiempo viejo del nuevo. Después, inde, de la expulsión del último rey, se nombraron dos cónsules en los comicios por centurias, convocados por el prefecto de la Ciudad de acuerdos con las normas de Servio Tulio. Fueron Lucio Junio Bruto y Lucio Tarquinio Colatino, o este Bruto y Marco Horacio, en Polibio ${ }^{55}$.

A tratarse de sucesos remotos, los autores clásicos formularon en sus relatos sus posiciones ideológicas, al tiempo que extraían pautas moralizantes de los episodios que relacionaban. Así, la percepción de conjunto de aquellos tiempos primitivos era que la monarquía se asimilaba al nacimiento de la Ciudad, y la República, como un nuevo sistema ya plenamente dotado y maduro, a aquel cuerpo jurídico que se contenía en las Doce Tablas. Más que los cónsules, por otro lado similares a reyes, el régimen republicano era el régimen de sus leyes, por lo que no hubo nuevo régimen de hecho hasta que no se aprobaron éstas, como un reflejo de su Derecho. Aunque en un texto incompleto y de transcripción confusa, para Polibio era una certeza que los

55 Dion. Hal. ant. 4.73.1-4; V.1.2; 7.41.1; Polib. 22.1; Liv. 2.1.2/3; 1.60.3/4. Un simple reflexión nos lleva a deducir que la organización centuriada de mediada la República, no podía existir en el siglo VI. Los romanos simplificaron el proceso de instalación de la República en orden a tapar la vergüenza de haber sido liberado por Porsena, por la unión de fuerzas de otros latinos y de Aristodemos de Cumas, Momigliano, A., "The Origins», op. cit. p. 94. Para GJerstad, E., Early Rome, op. cit. pp. 93 y 192, el consulado de L. Junio Bruto en 509, es pura ficción. Polib. 6.11b.10, elabora el retrato de un Tarquinio Prisco como rey justo y bueno. años centrales del siglo $\mathrm{V}$ a.C. - 30 años después de la invasión de Jerjes, 482 a.C., o sea, hacia el 452 - marcaron el comienzo de una nueva era de perfección en las instituciones políticas, que en su opinión, alcanzaría su plenitud 240 años después, más o menos cuando Roma empezaba a afrontar con éxito la guerra contra Aníbal. Según esto, a mediados del siglo V, se produjo en Roma el verdadero cambio institucional que la expulsión del último monarca no había traído, de acuerdo con la reflexión del megalopolitano ${ }^{56}$.

Cuando en la segunda mitad del siglo II d.C. Gelio hablaba del nuevo régimen que sustituyó a la monarquía, se refería a hechos que estaban a casi siete siglos de su tiempo. Sus citas sobre ese contexto histórico probablemente sólo pretendían dar la cobertura documental necesaria para situar correctamente las cuestiones literarias, gramaticales, jurídicas, filosóficas y de otras materias sobre las que el tratadista dirigía sus comentarios. Pero desde el punto de vista de un conocedor del Derecho como era Gelio, los verdaderos cambios del régimen político en la Ciudad vinieron con las nuevas leyes, no con las formas similares de desempeñar el mismo tipo de poder y sus atribuciones que se conocía desde la monarquía. Tras la expulsión de los reyes, el régimen fue significativamente similar al anterior, con cambios poco profundos que no afectaron a la esencia de un régimen fundamentalmente aristocrático. Este pensamiento también lo encontramos ya en el Principado en el jurista Pomponio y más tarde en Tácito. Para Gelio, como para los autores citados, el verdadero cambio de régimen, que transcendió el plano político, ocurrió a mediados del siglo V, con las Doce Tablas ${ }^{57}$.

56 Polib. 6.11.1; Liv. 34.6.8, del 195 a.C. La tradición romana se nutre de numerosos estereotipo, como el del tirano, el Soberbio, el malvado decenviro, de los tribunos y de la plebe, la mujer romana abnegada hasta el heroísmo - Lucrecia, Verginia, Clelia -. el púnico pérfido, los griegos mendaces y alocados, etc..., Aronson, E., El animal social, Madrid [1975] Madrid 2005, pp. 284 y 285; vid. RolLeR, M.B., «Exemplarity in Roman Culture: The Cases of Horatius Cocles and Cloelia», $C P h$ 99.1, 2004, pp. 1-56.

57 Gell. 11.18.6; tras la expulsión del segundo de los Tarquinios, lo único relevante fueron las Tablas, Tac. Ann. 3.26/27; Dig. 1.2.2.20, Ungern-STernberg, J. von, The Formation of the "Annalistic Tradition": the example of the Decemvirate», Social Struggles in Archaic Rome. New Perspectives on the Conflict of the Orders, ed. by K. A. Raaflaub, [The University of California Press, 1986], Oxford 2005, p. 92, n. 13. Para Liv. 3. 33,1, que sigue la tradición analística, las Doce Tablas fue el segundo cambio de la forma de estado, tras el que supuso el paso de la monarquía 
Sea ese tiempo, coincidente con la redacción de las Doce Tablas, o unos años antes, en conexión con la evolución de los conflictos militares con los etruscos, el hecho es que un sector de la historiografía actual rompe con la ortodoxia dictada por la tradición analística. Para algunos la República comenzó en el 504, tras la batalla de Aricia, poniendo el suceso en conexión con la retirada final de los etruscos, tras la derrota de Arrunte, hijo de Porsena. Otros lo llevan al año 495, tras la victoria romana del lago Regilo, y siguiendo la tradición, la muerte ese mismo año de Tarquinio el Soberbio. Pese a que la victoria de Roma en esa batalla sobre los etruscos y sus aliados puso fin a las aspiraciones del último Tarquinio, la realidad es que hasta el 474, en que se firmó una tregua de 40 años, Roma siguió guerreando de forma continua contra Etruria, en este caso con la ciudad líder Veyes, sola o en unión de otras ciudades etruscas, con episodios bélicos contra etruscos en el 483 , $480,478,477,476$ y $475^{58}$.

\section{CONCLUSIONES}

Un escaso repertorio de noticias, de contenidos poco relevantes y de origen dudoso en la mayor parte de los casos, obtenidos a partir de los relatos dejados por los llamados analistas, escritores cuyos usos retóricos desconocemos, y activos cinco siglos después de los hechos de los que se ocuparon, todo

a la República.

58 Liv. 2.42.8; 43.5; 44.7; 461-3; 46.7; 47. 6-8; 49. $1 ; 49$. 10-11; 50. 1; 50. 11; 51.2-4; 53. 1-3; 54.1; Heurgon, J., Roma, op.cit. p. 187. Comienzos de la República hacia el 470 a.C. y los fasti anteriores a ese año fueron falsificados por los pontífices del siglo III a.C., Werner, R., Der Beginn der römischen RepubliK: historisch-chronologische Untersuchungen über die Anfangs zeit der libera res publica, München 1963; los fasti anteriores a mediados del siglo V a. $\mathrm{C}$ eran de magistrados subordinados a los reyes, pues la República no empieza sino a mediados del V, GJerstad, E., Early Rome, VI, Lund, 1973, pp. 83 y 203; Martino, F. de, «In torno all'origen e della Repubblica romana e delle magistrature», ANRW I.1, Berlin /New York 1972, pp. 217249, 219. Cornell, T.J., Los orígenes, op.cit. rebajaba el periodo entre Rómulo y Prisco, a unos 75 años - 625/550 a.C. -, y hasta el 509 para los dos últimos. En la segunda opción, a los siete reyes tradicionales, se añadirían Aulo Vibenna, Tito Tacio e incluso Bruto, que habría ejercido como tal en el inicio de la República. Los intereses de la analística dejaron fuera a Porsena, y acaso habría habido otros cuyo nombre y momento fueron intencionadamente silenciados, Grandazzi, A., La fondation, op. cit. p. 268; Martinez-Pinna, J., "Tarquinio», op.cit. p. 74; Valditara, G., "A proposito di un presunto ottavo re di Roma", SDHI 58, 1988, pp. 276-284. esto fue el material con el que los historiadores augústeos trabajaron para elaborar las obras que conocemos. Con estos recursos, difícilmente podía ser diferente el relato sobre monarquía del que sus textos nos han legado. El número de reyes, la duración de sus reinados, y la necesidad de nutrir sus biografías con actividades de diversa índole, obligaron a los autores a complejos equilibrios retóricos y de composición para lograr trasladar al lector la necesaria coherencia que debía primar en sus obras, cuyo objetivo era ofrecer al lector u oyente una versión verosímil y en consecuencia creíble sobre la Roma de los reyes, sin renunciar al deleite de hacerlo como una pieza artística. Para ello, el autor usó de la inserción de discursos dramáticos, directos e indirectos, de episodios novelados y de amplia carga emotiva, y de la descripción de modelos morales, dignos de ser imitados por las generaciones subsiguientes.

Con relación a la tradición sobre los tres monarcas analizados, el discurso de Claudio y las pinturas de la tumba etrusca permiten algunas reflexiones que creemos que modifican en parte el cuadro narrativo tradicional, al menos como hipótesis a tener en cuenta. En la galería de héroes locales representados en aquella Tumba de Vulci, un individuo identificado como macstrna aparece liberando a un tal Caile Vibenna, héroe de aquella ciudad etrusca. En otra secuencia pictórica de la tumba otro personaje local, Marce Camiltnas, parece a punto de acabar con la vida de un tal Cneve Tarchunies Rumach, acaso el rey de Roma L. Tarquinio Prisco de la tradición, que habría sido derrotado por el citado héroe de Vulci. Varios siglos después, para Claudio, estudioso de la historia etrusca e interesado en mostrar a los senadores que una Roma gobernada por extranjeros era parte de la historia cotidiana de la Ciudad, citando a autores etruscos, aquel macstrna, que convierte en antropónimo, Mastarna, no era otro que el futuro Servio Tulio, que accedió al trono de Roma, tras la muerte de Tarquinio. El nuevo rey sustituyó su nombre etrusco por el latino por el que es conocido en una tradición literaria que el mismo emperador pudo conocer de Livio. Su acceso al trono, es explicada por Claudio, que lo situa a las puertas de Roma - Monte Celio - con los restos del ejército de este Vibenna, tras lo cual regnum summa cum rei publicae utilitate optinuit, concluye Claudio su alegato. Su interés político, sacar adelante su decreto de acceso de la nobleza gala a los honores de Roma, le obligaba a ignorar en parte la tradición 
historiográfica de Livio o Dionisio de Halicarnasos, que hablaban de Tulio como un rey de origen noble y latino, y prefería remitirse a fuentes etruscas, donde se informaba sobre la colaboración de este noble de Cornículo, con señores etruscos, en correrías comunes por la región, fuese como mercenario o en colaboración, como sodalis fidelissimus de un Vibenna, para un reparto ulterior de beneficios. Una pauta de vida frecuente y documentada en los relatos tradicionales sobre esos primeros siglos ${ }^{59}$.

Finalmente, los historiadores augústeos conciliaron el fin de la monarquía con la continuidad de la presencia etrusca en el nuevo régimen. Los primeros cónsules, L. Junio Bruto y L. Tarquinio Colatino, según la misma relación de los hechos, eran de origen etrusco, con estrechos lazos de sangre con el último Tarquinio. Pero el lastre que para el inicio del nuevo sistema político suponía que los últimos cinco dirigentes de la Ciudad estuviesen estrechamente vinculados a familias etruscas también fue resuelto de manera conveniente. Para Livio se trataba de L. Tarquinio Prisco, Servio Tulio, L. Tarquinio el Soberbio, y ahora los dos cónsules, L. Tarquinio Colatino y L. Junio Bruto. La noticia es así dada por el autor, que pese al origen latino que su propio relato asignaba a Tulio, en algún pasaje de su obra le incluía entre los dinastas etruscos. El historiador hablaba de lo insoportable que para los romanos fue el gobierno de los monarcas etruscos, y citaba ahora a cuatro - unas líneas más arriba nos refería al quinto, L. Junio Bruto, sobrino del Soberbio -. De esta forma, podía resultar inaceptable desde el punto de vista de las excelencias del régimen republicano que fuera un rey extranjero - un etrusco era un extranjero, un latino, un vecino - el que regulara las bases del aquel futuro estado, e igualmente, que Bruto, un miembro al fin y al cabo de la familia Tarquinia, según la filiación que la misma tradición construye, que liberó al pueblo romano de los etruscos, expulsando al Soberbio y luego al propio Colatino, al que obligó a dimitir como cónsul, que este primer cónsul no fuese identificado con trianomina plenamente latinizado, aunque le correspondiese en realidad una identidad distinta ${ }^{60}$.

59 Tras él, el último Tarquinio, el tercer etrusco, que llegó a se detestado en nuestra ciudad, y naturalmente el alma del reino se agotó - nempe pertaesum est mentes regni - y la administración de la república se trasladó a los cónsules, magistrados anuales, concluía el emperador.

60 En efecto, mediante un discurso en el que veía la necesidad de borrar del poder el apellido Tarquinio, Bruto le
Bibliografia

Alföldy, A. (1965), Early Rome and the Latins, Ann Arbor.

Ampolo, C., (1974), "Servius rex primus signavit aes", $P P, 29,382-388$.

Andreae, B. (2004), "La Tomba François”, Forma Vrbis, 9, 8-57.

Aronson, E. (1975), El animal social, Madrid.

Bianchi, L. (1985), "Il magister Servio Tullio", Aevum, 59.1, 57-68.

Blakeway, A. (1935), "Demaratus: A Study in Some Aspects of the Earliest Hellenisation of Latium and Etruria”, JRS 25, 129-149,

Briquel, D. (1990), "Le témoignage de Claude sur Mastarna /Servius Tullius”, BPH, 68, 86-108.

Buranelli, F., -a cura di-(1987), La tomba François di Vulci, Roma.

Cairo, G. (2010), “A propósito delle tradizioni sui Tarquini”, Gerion, 28.1, 75/95.

Capdeville, G. (1992), "Le nom de Servius Tullius", La Rome des premiers siècles. Légende et histoire, Actes Table Ronde en l'honneur de M. Pallottino (Paris 1990), Firenze, 47-67.

Cascio, E. lo (1988), “Ancora sui censi minimi delle cinque classi serviane", Athenaeum, 66, 273302.

Castagnoli, F. (1973/1974), "Topografía e tradizione storiografica su Roma Arcaica”, ARCL 25/26, 123-131, 127.

Coarelli, F. (1983), "Le pitture della Tomba François a Vulci. Una proposta di lettura”, DArch. $3^{\mathrm{a}}$ s. I. 2, 43-69.

(1990), “La crescitá urbana di Roma. Civiltá dei romani”. La cittá, il territorio, l'impero, Milano.

Colonna, G. (1977), "Un aspetto oscuro del Lazio antico: le Tombe del VI-V secolo", PP, 32, 131-165.

Cornell,T. J. (2005), Los orígenes de Roma, c. 1000 - 264 a.C. Barcelona.

(1986), "The value of the Literary Tradition concerning Archaic Rome”, Social Struggles in Archaic Rome. New Perspectives on

pide a Colatino que dimita y todos lo aprueban, de modo que éste se va con todas sus posesiones a Lavinio, convocando las centurias que nombraron como sustituto a P. Valerio. Decía de él que para no parecer enemigo de los que conspiraban contra su tío, se hizo el estúpido, permitiendo que hasta se apoderaran de sus bienes, y recibiendo por ello el cognomen de estúpido, Bruto, 54. 1; 34.3; 56.7-8; 2. 2.3-11; Dion. Hal. ant.. 4.12.1; 68.1; Zon. 7.12; DC 2.11.13. 
the Conflict of the Orders (K. A. Raaflaub, Ed.), The University of California Press, 1986, Oxford, 47-74.

Crawford, M.H. (1976), "The Early Roman economy", Melanges J. Heurgon vol. I, 197207.

(1996), Roman Statutes, II, London.

Fazio, M. (2000),"Porsenna e la società di Chiusi”, Athenaeum, 88.1, 2000, 393-412.

Fontana, G. (1991/1992), “¿Maxtarna en la tradición historiográfica romana? Un intento de reconstrucción de Festo, 486L", Veleia, VIII/IX, 439-448.

Fraccaro, P. (1957), "The History of Rome in the Regal Period” JRS, 47, 59-65.

(1957), "La storia dell'antichissimo esercito romano e l'etá dell'ordinamento Centuriato", Opuscula, II, 286-306.

Gabba, E. (1961), "Studi su Dionigi da Alicarnasso, II", Athenaeum, 39, 98-121.

(1998), "La Roma dei Tarquini”, Athenaeum, 86.1, 5-12.

(2000), "Problemi di método per la storia di Roma Arcaica”, Roma Arcaica. Storia e Storiografía, Roma, 11-24.

(2005), "Proposta per un quadro storico di Roma nel V sec .a. C.”, Le dodici tavole. Dai

decemviri agli umanisti (a cura di M. Humbert), Pavia 2005, 117-124.

Gagé, J. (1976), L a chute de los Tarquins et les debuts de la Republique Romaine, Paris.

Gantz, T.N. (1975) "The Tarquin Dynasty", Historia: 24.4, 539-554.

Giua, M.A. (1967), "La valutazione della monarchia a Roma in etá republicana”, SCO, 16, 308-329.

Gjerstad, E. (1969), "Porsenna and Rome", Orom, 7, 149-161.

(1973), Early Rome. VI, Lund.

Grandazzi, A. (1991), La fondation de Rome. Reflexion sur l'histoire, Paris.

Hafner, G. (1977), "Porsenna”, RdA, 1, 36-43.

Hammond, N.G.L. (2006), "The Peloponnese”, CAH, III.3, 321-351.

Hermon, E. (1984), "La période royale à Rome: Légende et histoire", Réflexions historiques, 11.3, 315-321.

Heurgon, J. (1986a), "La vocation étruscologique de l'empereur Claude", Scripta varia, Bruxelles, 427-432.

(1986b),"La coupe d'Auulus Vibenna", Scripta Varia, Bruxelles, 273-283.
Holloway, R. R. (1927), The Archaeology of Early Rome and Latium, Londres-New York.

Homo, L. (1927), Primitive Italy, London.

Hus, A. (1976), Les siécles d'or de l'histoire étrusque (675 - 475 avant J.-C.), Bruxelles.

Last, H. (1945), "The Servian Reforms", JRS, 35, 30-48.

Laurendi, R. (2010), "La monarchia etruca a Roma ed il nomen di Servio Tullio: epos e storia. Dati e considerazioni sulla Tavole di Lione e la Tomba François”, Polis, III, 123-146.

Levick, B. (1978), "Antiquarian or Revolutionary? Claudius Caesar's Conception of his Principate", AJPh, 99.1, 79-105.

Lewis, D.M. (2008), "The tyranny of the Pisistratidae”, CAH IV, 287-302.

Martinez Pinna, J. (1979), "El primitivo Templo de la tríada capitolina en Roma”, Bol. Real Acad. Bellas Artes de San Fernando, 48, 21723.

(1981), "Evidenza di un tempio di Giove Capitolino a Roma all'inizio del VI sec. a.C.”, Archeologia Laziale, 4, 249-252.

(1982), "Tarquinio Prisco y Servio Tullio", AEA, $55,35-61$;

(1987), "El intento revolucionario de Apio Herdonio", Gerion, 5, 87-96.

(1988), "La Roma de Anco Marcio”, Gerion, 6, 5688 ;

(1989), “Aspectos de cronología romana arcaica. A propósito de la lista real», Latomus 48.4, 798816.

(1996), Tarquinio Prisco, Madrid.

Martino, F. de (1977), "Postilla a riforme del IV secolo a. C.”, BIDR, 80, 51-53.

(1995), "Storia arcaica e diritto romano privato", Diritto, economia e societá nel Mondo Romano, I, Napoli, 387-407.

1972), "In torno all'origen e della Repubblica romana e delle magistrature", $A N R W$, I.1, Berlin /New York, 217-249.

Mattingly, H. (1937), “The Property Qualifications of the Roman Classes", JRS, 27, 99-107.

(1945), "The First Age of Roman Coinage", JRS, $35,65-77$.

Milne, J.G. (1942), “The aes grave of Central Italy”, JRS, 32, 27-32.

Momigliano, A. (1993), Ensayos de historiografía antigua y moderna, Wesleyan University Press 1947, México 1993, 94; idem, "An Interim Report on the Origins of Rome”, JRS, 53, 95- 
121.

(2005), "The Rise of the Plebs in the Archaic Age of Rome”, Social Struggles in Archaic Rome. New Perspectives on the Conflict of the Orders (K. A. Raaflaub, Ed.), The

University of California Press, 1986, Oxford, 168184.

(2006), "The origins of Rome”, CAH VII.2, 52-96.

Nilsson, M.P. (1929),"The Introduction of Hoplite Tactics at Rome: Its Date and Its Consequences”, JRS, 19, 1-11.

Ogilvie, R.M. (1982), Roma Antigua y los etruscos, Madrid, 22.

Pallottino, M. et alii (1978), Thesaurus Linguae Etruscae, Roma.

Pareti, L. (1958), "Mastarna, Porsenna e Servio Tullio", Studi minori di storia antica, I, Roma, 316-319.

Parise, N.F. (1991), Dal bue al bronzo. La misura del valore a Roma prima della moneta, Studi Romani, 39.1-2, 92-94.

Poucet, J. (2000), Les rois de Rome. Tradition et histoire, Bruxelles, 10.

Richard, J. Cl. (1983), 'L'Oeuvre de Servius Tullius: Essai de mise en point”, RHDFE, 61, 181-193.

(1987),"Recherches sur l'interpretation populaire de la figure du roi Servius Tullius", $R e$ vue de philologie, de litteraire et d'histoire anciennes, 61. 2, 205-225.

(2005), "Patricians and Plebeians: the Origin of a Social Dichotomy", Social Struggles in Archaic Rome. New Perspectives on the Conflict of the Orders (K. A. Raaflaub, Ed.), The University of California Press, 1986, Oxford, 98-110.

Ridley, R.T. (1975), "The Enigma of Servius Tullius", Klio, 57.1, 147-177.

Roller, M.B. (2004),"Exemplarity in Roman Culture: The Cases of Horatius Cocles and Cloelia", $C P h, 99.1,1-56$.

Sanctis, G. de (1992), "Mastarna”, Klio II, 96-104.

Scevola, M.L. (1975),"Conseguenze della deditio di Roma a Porsenna", RIL, 109, 3-27.

Scullard, H.H. (1980), History of the Roman World, 753-146 B.C., London.

Simone, C. de (2002), "Latino magister ("capo") etrusco mastarna - macstrna: che ordine di relazione?", RFIC, 130.4, 430-456.

Syme, R. (1939), The Roman Revolution, Oxford. Tamborini, F (1930), "La vita economica nella Roma degli ultimi re”, Athenaeum, 8, 299-328 y 452-487.

Thomsen, R. (1980), King Servius Tullius: a historical synthesis, Copenhague.

(1957), Early Roman Coinage, Copenhague.

Ungern-Sternberg, J. von (2005),"The Formation of the "Annalistic Tradition": the example of the Decemvirate", Social Struggles in Archaic Rome. New Perspectives on the Conflict of the Orders (K. A. Raaflaub, Ed.), The University of California Press, 1986, Oxford, 75-97.

Valditara, G. (1988), “A proposito di un presunto ottavo re di Roma”, SDHI, 58, 276-284.

Vernole, V.E. (2002), Servius Tullius, Roma.

Walsh, P.G. (1961), Livy, his historical aims and method, Cambridge.

Werner, R. (1963), Der Beginn der römischen 